part 4] PETROGRAPHY OF TORKSHIHE MILLSTONE GRIT.

13. The Peirrography of the Millstone Grit of Yorkshire. By Albert Gilligan, D.Sc., B.Sc., F.G.S., Lecturer in Economic Geology in the University of Leeds. (Read May 21st, 1919.)

[Plates XV-XVIII : Microscope-Sections.]

Contents.

I. Introduction 251

II. Petrography of the Millstone Grit

(a) Work of Dr. H. C. Sorby.

(b) Pebbles of Quartz.

(c) Do. of Felspar.

(d) Do. of Pegmatite.

(e) Do. of Igneous Rocks.

(f) Do. of Metamorphic Rocks.

(g) Do. of Sedimentary Rocks.

III. Examination of the Finer Material
(1) Quartz.
(2) Felspar.
(3) Mica.

IV. Heavy Minerals of the Millstone Grit 263 Table of Heavy Minerals.

V. Heavy Minerals in Pebbles found in the Millstone Grit . 272

VI. Lithological Characters of the Land-Mass from the Denudation of which the Material of the Millstone Grit was derived

VII. Divisions of the Millstone Grit Series .................... 275

VIJI. Mode of Accumulation of the Material.................. 276

IX. Position of the Ancient Land-Mass ................... 277

X. Physical Relief of the Ancient Land-Mass ............. 281

XI. Drift- or Current-Bedding in the Grit .................. 283

XII. Comparison with the Torridon Sandstone ............... 284

XIII. Climatic Conditions f............................ 287

\title{
I. In'troduction.
}

THE term 'Millstone Grit' is applied to a series of beds which attain a thickness of 5500 feet in Lancashire, consisting of conglomerates, grits, sandstones, and shales with occasional thin impure limestones and beds of chert. It occupies a position in the geological sequence between the Yoredale or Pendleside Group and the Coal Measures. For the purposes of this investigation the base of the Millstone Grit in West and North-West Yorkshire has been taken at the base of the Ingleborough Grit, following the precedent of the Geological Survey as pointed out in the Memoir on the Ingleborough District, 1890, pp. 74-75. Since this is a coarse grit, easily traceable on account of its lithological characters and the bold escarpments to which it gives rise, it forms a good 
datum-line. The top of the series has been taken at the top of the Rough Rock, where it can be seen to be overlain by the Lower Coal Measures, as at Whitehall Quarries, Horsforth, near Leeds. However, as no questions of correlation are involved in this work, the exact delimitations of the various beds is a matter of minor importance.

The Millstone Grit Series eovers an area in Yorkshire alone of no less than 840 square miles, and is important physiographically, as it forms the capping of most of the hills of the Pennine Chain, such as Mickle Fell, Whernside, Ingleborough, Penygent, etc., and by its presence there preserves the more easily denuded strata below from a more rapid destruction.

Economically the formation is of great importance, being extensively quarried for building purposes in the districts where it occurs, its value for this purpose being well understood by the Saxons and Normans, who used it in the construction of some of their noblest work. As the name implies, a brisk trade was at one time carried on in the making of millstones and grindstones from the grits and sandstones, their use for such purposes dating back to very early times. It also yields an excellent artesian supply of water, many boreholes for public and private works haring been made into this rock, and it is for this purpose being more exploited than ever in the neighbourhood of Leeds, Bradford, Huddersfield, and other large Yorkshire towns.

While, however, it has been generally known and valued for the purposes that I have mentioned, it has been undeservedly neglected by geologists as a subject for study from a purely scientific point of view. True it is that much excellent work has been done by Dr. Wheelton Hind, Dr. Wellburn, and others upon the marine fauna of the shales, but much more still remains to be done. The first and, so far as I am aware, the only worker to attack seriously the question of source and origin of the material making up this important series of rocks was the late Dr. Henry Clifton Sorby, who read a paper upon this subject before the Yorkshire Geological \& Polytechnic Society at its Annual Meeting in Leeds, March 17th, 1859. Since the publication of that paper, no systematic work has been done along the same lines until the present research was undertaken.

The methods of investigation made use of by Sorby have in a large measure been followed by me; but, in addition to the examination of the coarser material composing the conglomerates and grits, the finer material of the shales and the heary minerals obtained from the various beds have also been examined. Further, the area laid under contribution for material for this research has been much more extensive than that covered by sorby. It will, however, be seen that the results of my enquiry corroborate in a remarkable way the conclusions arrived at by that eminent geologist. 


\title{
II. Petrography of the Millstone Grits.
}

As was stated above, the grade of the material making up the beds of this formation varies considerably from a conglomerate with pebbles 2 inches or more in their longer axes to the exceedingly fine material making up the shales. From the coarser beds very large numbers of pebbles have been collected and examined microscopically, while sections of the finer grits and sandstones of different areas have been prepared and, in a few cases, of the shales also. The minerals of the finer-grained beds have also been examined, after suitable preparation by crushing, washing, etc.

\section{(a) Work of Dr. H. C. Sorlyy.}

Dr. Sorby, in the paper already cited, says ${ }^{1}$ :-

\begin{abstract}
' By far the commonest pebbles are of quartz like that forming one of the constituents of coarse-grained granites, but a considerable quantity are evidently portions of various yellow, pink, grey, and almost black quartzrocks or quartz-schists. There are also many pebbles of white or brownish orthoclase-felspar similar to that in coarse-grained granites, and it therefore becomes interesting to ascertain for certain whether some of the quartz and this felspar did not originally constitute a granitic rock. After much careful search, I have at length obtained extremely good proof of this fact, for I have found a few pebbles of undoubted granite, some of which are composed of a union of quartz and felspar like a coarse-grained granite, which are in every respect similar to the quartz and felspar so abundant as pebbles of each mineral alone. Besides such crystalline felspars there occur pebbles of finegrained felspathic rock with a few laminæ of mica, and though usually much decomposed it appears to have been some kind of eurite. I have also found one pebble of a moderately fine and even-grained rock much like some varieties of greenstone or a fine-grained syenite consisting of a white felspar and of a dark-coloured mineral, both too much decomposed to be accurately identified. It is also interesting on account of being the largest pebble I have yet found, for it is nearly 4 inches in circumference. With the exception of a single pebble of very fine-grained mica-schist, which some would call clay-slate, I have not found good examples of any other decided and well-marked rocks.'
\end{abstract}

\section{(b) Pebbles of Quartz.}

Anyone making a cursory examination of the pebbles of the conglomerate must agree with Sorby that quartz is the dominant type, forming the 'hummer' stones of the quarrymen. They also vary greatly in colour, among the varieties noted by me being black, rose, red, yellow, milky, blue or opalescent, and clear. 'The varying colours are, of course, due to inclusions of different types. The pebbles may be rounded or angular, but in all cases they show glistening surfaces due to the deposition of secondary silica. One striking fact with regard to their shape is the frequent occurrence of double sphenoid forms. Such forms suggest an origin from a coarse gneiss or pegmatite. The microscope reveals the fact that all these quartz-pebbles have been derived from rocks that have been subjected to mechanical deformation, which in

1 Proc. Yorks. Geol. \& Polytechn. Soc. vol. iii (1859) pp. 673-74. 
several cases has been of such an intense character as to produce a beautiful mylonized structure. Undulose extinction is a striking feature, both of the large and of the small quartz-grains. While examining the Kinderscout Grit (this name is merely used as a convenient term for the lower beds) of Burnsall Fell near Bolton Abbey, I found that much of the quartz of the medium-sized pebbles, and most of the quartz of the finer-grained portions. was either blue or opalescent in tint, and this was best seen where the surface had been bleached by a covering of peaty turf, or where the quartz was surrounded by kaolin.

A close examination of the other beds of the series, especially the Rough Rock, show that this blue or opalescent quartz is a common constituent. When examined in thin sections under the microscope, the colour is seen to be due in some cases to streams of minute rounded or irregular particles which are indeterminable; while in other cases, needles of rutile (?) occur in vast numbers, the streams crossing at angles of $60^{\circ}$ (see Pl. XV, fig. 2). Liquid inclusions with movable bubbles are common, both in the quartzpebbles and in the small grains of quirtz. The outline is frequently hexagonal or coffin-shaped, and the liquid is usually brown or amber in colour. The types of inclusions will be more fully discussed when dealing with the quartz of the finer material.

\section{(c) Pebbles of Felspar.}

'These pebbles are exceedingly interesting : they usually, when found in the coarser beds, retain a freshness which is remarkable, the lustre of the cleavage-surfaces being such as might be seen on the freshly-cleaved felspars of an unweathered granite. They vary in colour, but the majority are pink or flesh-coloured. The largest individual pebbles obtained by me have measured about $1 \times \frac{3}{4} \times \frac{3}{4}$ inch, and, curiously, they were embedded in what would be described as fine grit, being quite isolated from other pebbles and perfectly fresh quite to the outside. A considerable number of these have been sliced, and have proved to be invariably microcline or microcline-microperthite. Oligoclase is not at all uncommon in the finer material, while orthoclase is but sparsely distributed, and neither of these has been found as pebbles in any of the beds.

Mr. G. F. Pickering (of Horsforth), whom I have interested in this question, has kindly allowed me to examine a number of sections which he has made of these felspars, and, in all cases, I have found them to be microcline or microcline-microperthite. Another peculiarity of the felspar is the frequent occurrence in it of blebs of quartz (see Pl. XV, fig. 4).

\section{(d) Pebbles of Pegmatite.}

Almost as common as the felspars are pebbles of pegmatite, some of these measuring $\frac{1}{2}$ inch cube in the coarser beds. This type was apparently found and described by Sorby, but he gives no account of a microscopical examination of any of the pebbles 
which he found, and evidently believed all the large felspars and that associated with the quart\% in his ' coarse-grained granite' to have been orthoclase. I have stated above, when describing the felspar-pebbles, that orthoclase is either extremely scarce or absent as large pebbles. Similarly, an examination of these pegmatites in thin sections under the microscope shows that the felspar is, with one exception, microcline or microcline-microperthite. 'The one exception is, however, of extreme interest. It is the largest piece of pegmatite yet found and was presented to me by Mr. J. Holmes (of Crosshills), to whom I am also greatly indebted for other valuable assistance. Before being broken it measured $5 \times 2 \frac{3}{4} \times 2 \frac{1}{2}$ inches, and was found in the Middle Grits near Silsden. The felspar in this case is albite, and so the rock would be termed a soda-aplite. The quartz associated with the felspar in these pegmatite pebbles is usually blue or opalescent, and shows undulose extinction, but not the mylonized structure so common in the large quartz-pebbles. Mica (muscovite) is only sparingly present in these pebbles. The pebble which Sorby named a eurite would almost certainly belong to this group.

\section{(e) Pebbles of Igneous Rocks (other than those of the Aplite-Pegmatite Family).}

A remarkable assemblage of pebbles consisting of igneous and metamorphic rocks has been obtained from the Middle Grits and Rough Rock of the Aire Valley. Many of these pebbles measured, before being broken for examination, as much as $6 \times 3 \times 1$ inches, while one measured $10 \times 8 \times 4$ inches, and is the largest yet recorded from the Millstone Grit. Occurring as they do in beds which are fine-grained, it is interesting to enquire as to the manner in which they were transported. The bed in which they occur is crowded with plant-remains, and I was told by the workmen that numerous trunks of trees had been unearthed during quarrying operations. This would seem to afford a sufficient explanation, the pebbles having been carried down by drifting vegetation. The remarkable angularity of some of the specimens would also lend support to this theory; but it is not so easy to explain how the plants of the Carboniferous Period such as Sigillavia, Lepidodendron, etc., with the long horizontal roots, could have obtained so strong a hold upon these large blocks as to transport them for any great distance, such as I conceive these must have travelled. The problem is similar to that of the occurrence of the quartzite and granitic pebbles and boulders found in coal-seams, and I believe that the agency suggested above explains both cases.

The types of igneous rocks represented are the following :Granites, quartz- and felspar-porphyries (several specimens of each) and quartz-diorite (one specimen).

The granites are always pink or flesh-coloured and fine-grained, no porphyritic crystals having been present in any of them. The usual type is a two-mica granite with orthoclase and plagioclase 
felspars, and showing micrographic structure, generally somewhat fine.

The quart\% in most cases shows undulose extinction, and the lamina of the micas and felspars are often curved. A notable feature is the frequent presence of such accessory minerals as zircon and rutile, included often in the quartz and felspar, hut usually in greatest quintity in the micas. 'This last point is of interest, in view of the work which has been carried ont by me upon the heary minerals of the Millstone Grit, and presented in a later part of this papar. Perhaps the most noteworthy of these granite-pebbles is that illustrated in Pl. XVII, fig. 4, which in the hand-specimen shows a distinct gneissose structure; but, when examined in polarized light, it is found to yield no evidence whatever of crushing, and is a particularly fine example of a protoclastic granite or gneiss, the intense foliation having been produced prior to its final consolidation.

The quartz- and felspar-porphyries are usually buff-coloured, with the quartz and felspar (the latter often altered) well seen on the broken surface. The porphyritic crystals are often much corroded, especially the quartz, and the felspars are commonly microclme or microperthite with a tendency to micrographic structure as an outgrowth from some of the felspar-crystals. Liquid inclusions with movable bubbles are abundant in the quart\% of a number of these rocks. 'The ground-mass is of the usual microcrystalline type, in which small wisps of biotite frequently occur. One of these porphyries bore so striking a resemblance to the well-known rhomb-porphyry of the Christiania district that it was sent to Prof. $\mathbf{W}$. C. Brögger for determination. He stated that it was not a true rhomb-porphyry, but said that it was possibly one of its facies, the rock being too much decomposed to make the identification certain.

The quartz-diorite pebble is the only one of basic trpe ret found.

\section{(f) Pebbles of Metamorphic liocks.}

Sorby records the finding of a single pebble of tine-grained mica-schist or clay-slate, and suggests that their scarcity is accounted for by the ease with which such rocks would be broken up during transport. I can but endorse Sorby's remarks upon the rarity of pebbles of schist through the Grit Series as a whole; I have, however, been fortunate enough to obtain a number of large pebbles of schists and gueisses from the Middle Grits of Silsden. Indeed this has been the 'happy hunting-ground' for the igneous and metamorphic pebbles.

The granitoid gneisses are composed of practically the same minerals as the granites described above, only differing in the structures produced by shearing. In fact, there is a regular gradation quite noticeable when the sections are compared. The schistose rocks form an important group. Generally, they may be described 
as mica-schists and quartz-schists. The former show contortions with minute foliations and strain-slip cleavage. Among these pebbles is found one which may provide a clue to some of the problems concerning the source whence the material of the grit was derived (see PI. XVIII, fig. 2). It has been identified both by Prof. T. G. Bonney and Mr. G. Barrow as coming from the Blair Athol district. Mr. Barrow writes :--

"This is the "Black Schist" associated with the Blair Athol-a-Nain Highland Limestone. Along a great belt of country the lower part of this rock is known as the "Felspar-Rock" of Glen Callater, as that was the place where it was first found. It suceeeds a rock especially rich in peculiar forms of chlorite, and there is much of this chlorite still in the lower part of the bed altering to the Felspar-Rock, but less as we ascend. This rock is from the lower part of the "Felspar-Rock" ; it contains the felspar (pale-grey under crossed nicols) first determined by Sir Jethro Teall, and in this felspar is the typical dark dust. In addition the pale, almost white chlorite is present in considerable quantity, and the characters of the rock as a whole make it quite unmistakable.'

With this schist must undoubtedly be placed, as allied in origin, some of the others, as they contain the pale chlorite, and present a general family resemblance.

Some of the schists are garnetiferous, and thus help to explain the common occurrence of garnets in the grit-beds; while tourmaline, though not previously discovered in the sections prepared of these rocks, is nevertheless found in considerable quantity in the hearymineral separations. Zircons are plentiful, while rutile is also fairly common in some of them.

A few pebbles of slightly-altered sedimentary rocks have also been found.

\section{(g) Pebbles of Sedimentary Rocks.}

In the beds of coarse grits at the base and top of the Millstone Grit Series, and in the coarser bands of the Middle Grits, occur numerous pebbles of chert. These are usually black and therefore easily detected, but others are buff, brown, or yellow. Generally, they present the ordinary characters of such rocks when seen under the microscope. Many of these chert-pebbles from the Kinderscout Grit of Upper Wharfedale and Airedale have been sliced and compared with specimens of chert from the Carboniferous Limestone Series; and it has been found that, while organic structures are usually present in those from the Carboniferous Limestone, only a few from the grits show any traces of organisms and then of quite a different nature.

One of the chert-pebbles (see PI. XVIII, fig. 4) found in the Kinderscout Grit of The Strid, Bolton Abbey, shows beautifullydeveloped oolitic structure. From the Plumpton Grit at Grimbald's Crag, Knaresborough (exposed in the river-bed), was obtained a very curious grey pebble (see PI. XVIII, fig. 5), which, in the handspecimen, shows a number of circular pits suggesting oolitic structure. In many parts the pebble is stained with hæmatite. 
Under the microscope the structure is even more remarkable, presenting the appearance of a completely silicified oolite. 'The concentric structure characteristic of oolites ean be traced in many cases. The matrix is cryptoerystalline and microcrystalline silica, and the oolitic grains are irregularly distributed through the rock. No radial structure can be distinguished in any of the oolitic grains. Each of the original oolitic grains is now outlined by a number of small spherical bodies which are each stained with oxide of irun. The diameter of these bodies is, on the average (PI. XVIII, fig. 5), .02 to $.03 \mathrm{~mm}$. Similar rounded bodies can be seen scattered through the ground-mass, and showing a tendency to group together by twos and threes. In many of these, when using a high magnification, can be seen a spherical nucleus stained with hæmatite, while the rest of the body is quite clear. The clear part has a somewhat higher refractive index than the silica making up the ground-mass of the rock. The bodies were at first suspected as being of organic origin, but the late Dr. G. J. Hinde, who kindly examined the section for me, failed to identify them as being derived from organisms. In the Geological Survey Memoir on the North-West Highlands of Scotland, is described and figured a pebble from the 'Torridonian which agrees in a most remarkable way with the one here described.1 Silicified oolitic Durness Limestone kindly supplied to me by Dr. John Horne, F.R.S., has been examined for comparison, but proved to be quite unlike this specimen, none of the curious spherical bodies being found. The Rough Rock of Whitehall Quarries, Horsforth, has also yielded a pebble with well-developed oolitic structure, so that they have been found in the Lower, Middle, and Upper Grit beds, but they are not of frequent occurrence by any means. Another pebble from the Rough Rock of Horsforth shows traces of organisms when a section is examined by ordinary transmitted light (see Pl. XVIII, fig, 6). They seem to be tubular bodies which have been cut through in different directions. Some of the tubes appear to be quite straight, while others are curved. No structure can be observed even when a 1/9 objective is used. In polarized light almost all trace of the organisms disappears, and the rock looks like a very fine-grained arenaceous mudstone in which somewhat larger angular pieces of quartz are irregularly distributed. Inside these angular pieces of quartz, which is very clear, can be traced the circular sections of the tubular organisms (by transmitted light), and this seems to point to a secondary growth of silica round the organisms.

A black siliceous pebble from the Kinderscout Grit of Embsar Moor shows traces of organisms; these appear to have been brachiopods and sponge-spicules, while a very similar pebble showing organisms was obtained from the grit of The Strid, Bolton Abbey.

1 'North-West Highlands of Scotland' Mem. Gzol. Surv, 1907, p. 280 \& pl. l, fig. 1. 
The quarrymen engaged in working the various grits are only too familiar with the frequent occurrence of discoidal masses of shale, which are often in such numbers as to render worthless the large blocks for which the beds are worked. I have examined a great number of these, and have found them to be of ordinary micaceous shale, exactly similar to the shales of Carboniferous age such as the Yoredales or Millstone Grit. In a large specimen found in the Rough Rock at Horsforth, fossil plant-remains have been obtained. These were submitted to Dr. R. Kidston, F.R.S., who pronounces them to be Cordaites borassifolius. The origin of these shale-masses is somewhat obscure. Do they represent small mud-puddles infilled at the time of the accumulation of the surrounding coarse material, or are they true pebbles derived from a consolidated shale? The small masses, 1 inch or less in diameter, lie in all directions in the grit; they seem to be transported, and may possibly represent fragments of clay-slate or a similar rock, indeed one such piece has actually been found. The larger pieces lie more or less parallel to the bedding, and seem to be of contemporaneous origin. Furthermore, these latter have the impress of the surrounding grit, while many of the smaller pieces are quite smooth.

\section{Examinatron of the Finer Material.}

The Millstone Grit has been described as an arkose, and no better name could be employed, as it is neither more nor less than a disintegrated granitoid rock which has been reconsolidated.

The rocks which have contributed the material were certainly acid in composition, the quantity of minerals characteristic of basic rocks being of such an order of magnitude as to be quite negligible. A cursory examination of a hand-specimen of the grit shows quartz and felspar, with occasional flakes of mica and often garnet. While, however, mica is not so commonly found in the coarser beds, it is of such abundance in some cases as to make up beds of practically pure micaceous material 2 to 3 feet thick, such as that below the Rough Rock of Keighley Moor; while in the flaggy beds it determines the planes of division.

\section{(1) Quartz.}

The grains vary greatly in the degree of angularity, many being quite rounded in some of the lower beds (those examined from the Kinderscout Beds of Upper Wharfedale show several rounded grains) and also in some of the Middle Grits, such as that of St. Helen's Quarry, Spofforth (Follifoot Grit). In the Rough Kock very few have been found: indeed, they may be described as lare. Much of the angularity is, however, due to a deposit of secondary silica upon the original grain, as is so well seen on the surfaces of the larger pebbles of quartz. It may here be noted that the quartz-grains found in a sandstone near the top of the Carboniferous Limestone at Hoff Beck, Appleby, and quite near 
to the outcrop of Millstone Grit of that area, are beautifully rounded, resembling, indeed, in this respect, those of the Penrith Sandstone of the same district. It may, therefore, be that the rounded grains in both the sandstone mentioned above and in the Millstone Grit have been derived from sand-dunes which rrınged the coast of the Carboniferous sea, but I an inclined to believe that they were derived from beds of pre-Carboniferous age, for reasons which will be brought forward later.

The grains vary greatly in size, the larger showing the higher degree of rounding, as (of course) is usual. Nothing will be gained by describing in detail the size of the grains; suffice it to say that the larger grains are found in the Kinderscout Grit and Rough Rock, while, as a rule, the Middle Grits are much finer. When examined microscopically, most of the quartz shows (like the larger pebbles) that it has been derived from rocks which have been subjected to mechanical deformation, in that undulose extinction, with crenulate and mylonized structure, is common. The larger grains show these features better than the smaller. The following percentages have been obtained, by taking typical sections of the grit of varying degrees of coarseness :-

\begin{tabular}{lllll} 
& \multicolumn{4}{c}{ Per cent } \\
Coarse beds : Grains showing signs of pressure & 84 \\
Medium beds : Do. do. do. & do. & 62 \\
Fine beds : & Do. do. & do. & do. & 45
\end{tabular}

The reasonable deduction is that most of the quartz was derived from such rocks as granitoid gneisses and schists.

\section{Inclusions in the Quartz-Grains.}

It may be stated, first of all, that no single grain of quartz entirely free of inclusions has been detected in any of the sections of the grit examined: it being most usual, indeed, to find them crowded with inclusions. The inclusions are of many different kinds, and comprise the following :-

(a) minerals showing good crystal form; $(b)$ acicular crystals possibly of rutile; $(c)$ glass, gas, and fluid cavities; and $(d)$ black dust quite indeterminable, and occurring both irregularly and in rows and streams.

The researches of Dr. W. Mackie on the quartz of granites, gneisses, and schists of Scotland have shown that the type of rock from which the grains have been derived may be deduced from an examination of these inclusions. ${ }^{1} \mathrm{He}$ has classified the inclusions as follows:-

I. Regular (these would include those under (a) above).

II. Acicular ( Do. do. do. do. do. (b) do. ).

III. Irregular ( Do. do. do. do. do. (c) and some (d) above).

IV. Negative (that is, without inclusions, or where inclusions of the irregular type are so small as practically to escape notice).

i Trans. Edin. Geol. Soc. vol. vii (1897) pp. 148-72. 
Further, Dr. Mackie remarks :

'It may be stated as a fairly general law that acicular and irregular inclusions pre-eminently abound in the quartz of granite; that the regular group is to be found in various proportions, but always in relatively large numbers, in the quartz of gneiss and the younger schistose rocks.'

He also states that, in his work on the Scottish rocks, inclusions of different kinds occur frequently in one and the same grain, and then such a grain is classed under the heading of 'acicular' or "regular" if these forms are present at all.

Among the minerals of good crystal form included in the quartz of the Millstone Grit, and termed 'regular' inclusions, are the following (in decreasing order of relative abundance):-zircon, tourmaline, rutile, and oxides of iron.

The acicular inclusions appear to be almost invariably rutile, though tourmaline and sheaf-like aggregates, which may be sillimanite, have been rarely seen.

In their order of relative abundance, the inclusions may be classed as follows :--regular, irregular, acicular, negative. (These last are almost negligible).

It follows from Dr. Mackie's determinations that the deduction from the inclusions is in agreement with that previously made: namely, that the quartz has been derived for the greater part from rocks which have been subjected to pressure. Again, the frequent occurrence of streams and rows of the irregular inclusions is a feature which reminds one of the inclusions in such a rock as the Lewisian Gneiss, of which I have had sections prepared for comparison.

Sir Jethro Teall states, regarding the inclusions in the blue quartz of the pyroxene-gneisses with quartz of the North-West Highlands, ${ }^{1}$

"These are of four types: (1) rows of minute dots; (2) extremely thin hairs, formed in all probability of the same substance as the dots ; (3) cavities with very dark borders; and (4) minute irregular flecks and grains. . . . . A similar blue quartz occurs in the grits of the Southern Highlands, and there also it contains the minute hairs and rows of dots........ it seems probable that this colour is due to the inclusions.'

All the types mentioned by Sir Jethro Teall are present in the quartz of the Millstone Grit; and further, as was stated previously in the description of the larger quartz-pebbles, liquid inclusions, usually hexagonal or coffin-shaped and with movable bubbles, are common. 'The relative size of the bubble to the fluid-cavity differs greatly in the various grains, which points to the fact, as Sorby has shown, that they have been derived from rocks which have solidified at different temperatures and pressures, the ratio of bubble to cavity being of course greatest in those which have solidified at the greatest depths, and therefore probably from the highest temperature. The highest ratio of bubble to cavity is about 0.25 ,

1 'North-West Highlands of Scotland' Mem. Geol. Surv. 1907, p. 54.

Q. J. G. S. No. 300 . 
while the lowest is about 0.075 . It is of interest and importance to note that liquid cavities with movable bubbles occur in the quartz of the granite, gneiss, and quartz-porphyry pebbles described in an earlier part of this paper.

\section{(2) Felspar.}

The grains of felspar are commoniy well rounded, as is usually the case in sedimentary rocks, and often somewhat elongated, this form having been determined by cleavage. As with the larger pebbles, the dominant felspar in the finer material is microcline, next in order comes microcline-microperthite, then oligoclase, and orthoclase. Very basic felspars appear to be altogether absent in the fresh state, and were never, I believe, present in any notable quantity. 'These felspars are often exceedingly fresh. As in the larger pebbles, the cross-hatching of the microcline is wonderfully well shown, while the oligoclase is frequently quite unaltered (Pl. XVI, fig. 1).

Microcline is, as is well known, the most resistant of the felspars to alteration, and is found quite fresh in deposits of all ages. 'The oligoclase and orthoclase are, however, much more readily decomposed, and their freshness here has a deep significance, which will be emphasized and discussed when the mode of derivation and accumulation of the material comes under consideration.

It appears probable, from the frequent association of calcite with decomposed felspar, that the original form of the felspar had been one of the less basic soda-lime group. This was especially well seen by me in some sections of the grit from a borehole at Meanwood, Leeds.

An investigation into the question of the original freshness of the felspar and its alteration by subsequent atmospheric action was made by means of sections cut of the grit from a deep boring at Bradford, and it was found that, as a general statement, it may be asserted that the percentage of fresh felspar increased with the depth from which it was obtained. In this connexion a further confirmation is to hand in the fact that it sometimes happens that a borehole put down in the grit for water fails to tap the supply, since the density of the rock approaches that of a true granite, and hence its porosity is very low. The rock has to be blasted at the bottom of the borehole, so as to open up a connexion with a joint through which the water may find its way to the borehole.

\section{Inclusions in the Felspars.}

Quartz-blebs are very common in the microcline, while zircon, tourmaline, and rutile also occur, but of these zircon is by far the commonest. Muscovite, as a primary inclusion and not due to. decomposition, is also fairly common. 
(3) Mica.

In the coarse grit-beds mica is not plentiful, but becomes an increasingly important constituent as the fineness of grain of the rock increases, until in the shales it becomes the dominant mineral. The potash-micas are the most plentiful in the flags and sandstones, while the ferromagnesian micas are much more common in the shales. It may be that much of the mica in the shales is of secondary origin, as suggested by Mr. W. M. Hutchings for the mica in the shales of the Coal Measures. ${ }^{1}$

The size of the mica-flakes is important, ranging up to a quarter of an inch in diameter in some of the very micaceous beds, such as that on Keighley Moor; while similar large micas were observed in the shales obtained from deep boreholes at Leeds and Bradford.

\section{Inclusions in the Micas.}

These are rery frequent in the ferromagnesian type, and, in addition to the oxides of iron which occur along the cleavageplanes, zircons are extremely common. These are surrounded by the usual pleochroic haloes. It seems quite clear that the excellence of the crystalline form of the zircons obtained from the shales and grits can best be explained by supposing them to have been carried along as inclusions in the micas, and only released by the decomposition of the mica in the place where they are now found.

\section{Heavy Minerals of the Millstone Grit.}

From the commencement of my investigations I have been able to identify many of the so-called 'heavy minerals' in the ordinary sections of the grit which I have had prepared, and this is notably the case with the zircons, garnets, and tourmaline; but, for the more detailed examination of such minerals, recourse was had to the following method of separation. The grit; sandstone, or shalespecimen, weighing approximately 1000 grms., was pounded, but not ground, in a mortar, and, when thus prepared, was placed upon the coarsest of a series of sieves of 10,30, 60, and 90 mesh to the inch respectively, and very thoroughly shaken. It was found that almost the whole of the heavy minerals were passed by the 90 mesh, this being especially true of the zircons, rutile, and monazite. From some of the beds, garnets large enough to be retained above the 60 mesh were numerous; but, of course, this was known by examination of the specimens with a hand-lens. After dealing with some twenty specimens by separating the heavy minerals from all the grades which passed the 10-mesh sieve, I found that it was sufficient to examine the material in the following way:-

Shales-material which passed the 90 mesh.

Sandstones- Do. do. do. do. 60 and 90 mesh.

Coarse grit- Do. do. do. do. 30, 60, and 90 mesh.

${ }^{1}$ Geol. Mag. 1890, pp. 263-316, \& ibid. 1894, pp. 36-45. 
The finer material or dust, caused by the pounding, and still adhering to the grains, or present in large proportion in that which had passed the 90 mesh, was removed by washing and decantation. When it was deemed necessary, the material after washing was treated with dilute hydrochloric acid to remove the iron oxides. After washing and drying, some were mounted for examination with the microscope in order that the character of the grains and the relative abundance of the heavy minerals might be noted. The separation was carried out with a Sollas bottle and Thoulet's Solution of specific gravity $2 \cdot 8$.

\begin{tabular}{cc}
\multicolumn{2}{c}{ Heavr Minerals Present. } \\
Cubic System. & Tetragonal. \\
Garnet. & Anatase. \\
Iron Pyrites. & Rutile. \\
Magnetite. & Zircon. \\
& Xenotime. \\
Hexagonal-Rhombohedral. & Orthorhombic. \\
Calcite. & Andalusite. \\
llmenite. & Barytes. \\
Tourmaline. & Brookite \\
& Topaz. \\
Monoclinic. & Triclinic. \\
Monazite. & None.
\end{tabular}

In addition to these, the following minerals were present in practically all the separations:-Leucoxene-as an alterationproduct of ilmenite; small rounded grains of limonite and clayironstone. Pyrolusite is often present as a cement in some of the coarser beds, and the presence of manganese was proved in many cases by chemical tests.

\section{Description of the Heavy Minerals.}

Garnets.- These are by far the most abundant of the heavy minerals in the coarser beds of the. Kinderscout Grit and Rough Rock. Some garnetiferous layers were found in the Rough Rock of Cragg Hill Quarry, Horsforth, in which they occurred in such quantity as to form the dominant mineral species. They are very variable in size, the largest grains measuring as much as 1.0 to $1.5 \mathrm{~mm}$. in diameter. They are generally of a rich pink colour, but many of a deep wine-red colour also occur.

In the garnetiferous layers they show evidence of having undergone alteration to some chloritoid substance by which they are surrounded in pits, and the whole surface of the layer is deeply stained with oxide of iron. Indeed, this characteristic pitted appearance and colour of these layers has enabled me to collect specimens from the heaps of broken rubble in the quarries. Where the garnets are in contact with the large pebbles of quartz, the quartz itself is pitted, which is due doubtless to some chemical interaction between the garnet and the quartz. 
Under the microscope the larger grains are seen to be fairly rounded, but the smaller ones are angular, this being due to the extraordinary development of the dodecahedral cleavage (best seen in the small garnets which occur in the shales of the Grit Series, and it is also the characteristic feature of the garnets that I have separated from the sandstones of the Coal Measures). Dr. T. O. Bosworth ${ }^{1}$ has noted a similar peculiar angularity in the garnets found in the Coal-Measure sandstones in Scotland, and the figures given by him could well be taken to represent the garnet-grains of the Millstone Grit and Coal-Measure sandstones of Yorkshire.

Another remarkable feature is the skeletal or drusy development shown by a very large proportion of the larger grains, the rhombic faces of the small individuals that make up the grains being easily observable. Deep pits with apparently rhombic section also occur in the grains, though perforations are somewhat rare.

Inclusions are very common in the larger grains, so much so that the grains are seldom isotropic. The nature of these inclusions has not been determined with certainty, but most of them are of some mineral with strong double refraction, occurring either as stumpy prisms, or long slender needles; while others, again, are of irregular outline.

Chemical and spectroscopic tests show that the garnets are chiefly of the almandine type.

Iron Pyrites.-This mineral is not nearly so abundant in the Millstone Grit as in the Coal Measures. It occurs generally as small cubes or rounded grains.

Magnetite.-In none of the separations is this mineral abundant. It is mostly in the form of rounded grains, but some of octahedral form have been found. As one would expect, it is most abundant where ilmenite is also common.

Anatase.-As separate grains which may be of primary origin, this mineral is rare; but, as a secondary outgrowth from leucoxene, it is abundant. The stages can be traced as follows:-ilmenite, leucoxene, anatase, or rutile. It is colourless, and of tabular habit, with low pyramids developed in some cases.

Rutile.--In some separations this mineral is very abundant, indeed, it is the most abundant heavy mineral in some of the shales. It has proved to be invariably present. The colour varies from light yellow, through deep amber and brown, to foxy red. It may be said that the deep amber and brown are the most abundant. Many crystals show an almost complete development of the faces with sharp edges. In other cases the prism-faces only are well developed, and the terminations irregular or rounded.

1 'The Heavy Minerals in the Sandstones of the Scottish Carboniferous Rocks' Proc. Geol. Assoc. vol, xxiv (1912) pp. 57-61 \& pls. x-xi. 
Geniculate or cordate twins are extremely rare, and only a few cases of polysynthetic twins have been noted.

Colourless rutile after leucoxene has been noted in many cases.

Zircon is present in every bed that has been examined, but is by far the most abundant in the micaceous and arenaceous shales, fine-grained grits, sandstones, and flags. Of the true gritbeds it is of most frequent occurrence in the beds comprising the Middle Grits, notably in the grit of Addingham Edge and the associated beds. While well-developed crystals are found in all the beds, the highest proportion is in the micaceous beds, and here the sharpness of outline is most striking. It would suggest, as mentioned above, that they have been transported to their present position enclosed in some mineral, possibly a ferriferous mica which has decomposed and released the zircon. There is confirmation of this hypothesis in the fact that, in several sections of the grits, biotite is found enclosing zircon. The crystals vary much in habit, the ratios of length to breadth varying from $2: 1$ to $6: 1$, the greatest proportion being about midway between these limits.

Lengths measured on good crystals :- $\cdot 09, \cdot 18, \cdot 25, \cdot 30, \cdot 35 \mathrm{~mm}$.

\section{FORMS OBSERVED.}

Prisms 100 with pyramids 111.

Prisms 100 and 110 with pyramids 311 and 111.

Prisms 100 and 110 with pyramids 111.

Prisms 100 with pyramids 111 and basal plane 001 .

These last are somewhat rare.

The terminations in many cases are rounded, owing to the development of a large number of pyramid faces.

No capped crystals have been found, although a very careful look-out has been kept for them

One twinned crystal similar to that figured by Mr. R. H. Rastall \& Mr. W. H. Wilcockson from the microgranite of Threlkeld Quarry, near Keswick, ${ }^{1}$ has been found.

Zonary structure is common, though it does not seem to be characteristic of any particular habit. The zoning is more common in the central part of the crystals than in the outer portions.

Inclusions are numerous, and consist of the following types:-

(1) gas and glass inclusions of various forms, a tubular form being common; (2) other minerals, usually with regular outline, and including zircon (xenotime) and possibly apatite; (3) negative crystals.

It has very frequently been observed, when using a high magnification, that the inclusions themselves contain inclusions, especially those of tubular form. The inclusions are, in some cases, zonally arranged, and lie with their long axes parallel to the faces of the crystal. It is impossible to photograph these inciusions so as to show their abundance in any single case, as they, of course, do 
not lie in the same plane, and hence it requires a careful search by racking the microscope up and down for each crystal to examine them adequately.

The zircons are for the most part water-clear, though some are cloudy. Associated with the zircons, as regards form and optical properties, are some reddish and reddish-brown crystals which are possibly xenotime. These are often clouded with alterationproducts.

Calcite.-In some of the separations made from the Rough Rock derived from a borehole at Meanwood, Leeds, considerable quantities of calcite were obtained by using liquid of sp. gr. $2 \cdot 7$. In the microscopic sections of the same beds the calcite was seen to form. the matrix in a large part of the section. It is worthy of note that the calcite was found to be most abundant, as one would naturally expect, in proximity to shales yielding a marine fauna. It cannot be said that calcite commonly acts as a matrix to the grit; and it has not been found in any quantity, except under the conditions mentioned above.

Ilmenite.-Of the iron-bearing minerals this is by far the commonest, if we exclude the limonite which is so abundant as a matrix and the grains of clay-ironstone. In nearly all cases it forms the core of an aggregate of leucoxene, anatase, and rutile crystals, to which it has given rise.

Tourmaline.-This mineral is of very common occurrence throughout the Millstone Grit Series. Good crystal outline has frequently been observed, and is in all cases that of the prism terminated by rhombohedra. The grains have often been so worn as to be almost spherical. 'The colour is very variable, but some shade of brown is the dominant one. Blue tourmaline is frequently present; the colour, however, is seldom very intense. The pleochroism of the brown variety is strong, while that of the blue is much weaker.

Inclusions are not common, but (when present) are small and indeterminable.

Barytes.-Like the calcite this acts as the matrix in many cases, and has only been separated in any quantity from the grit of one locality, namely, Great Almscliffe Crags (Kinderscout Grit) of Wharfedale.

Brookite.- Only one undoubted grain of this mineral has been found. It has a pale-yellow colour, and the pleochroism is weak. The striations parallel to the vertical axis are well developed.

Monazite.-Of all the heavy minerals this is certainly the most important and interesting. Its presence had long been suspected in the separations from the Rough Rock; but, when the garnetiferous layers were found and separations made, the honey-yellow grains of monazite were so plentiful that its identity could be 
established beyond doubt. For this purpose, both chemical and spectroscopic tests were made. 'The grains are generally rounded, though a few of fairly-good crystal outline occur. Often it is clouded with brownish alteration-products.

Its presence has now been determined in many of the beds of the series from the Kinderscout Grit to the Rough Rock. Nowhere, however, has it been found in such abundance as in the garnetiferous layers of the Rough Rock at Cragg Hill Quarry, Horsforth.

I think it desirable here to point out that I have paid visits to the Cragg-Hill and Whitehall Quarries, Horsforth, much more frequently than to any other locality, on account of their proximity to my home; also that, by having them under such close observation, I have been enabled to discover here the garnetiferous layers: they may occur in just as great abundance elsewhere. I am convinced, therefore, that exact statements regarding the abundance or otherwise of minerals in sedimentary deposits must be made and received with caution, unless such statements refer to a succession of beds in a quarry-face, section, or borehole, or where horizons can be definitely correlated. For example, these garnetiferous layers which have yielded such an abundance of heavy minerals are from a quarter to half an inch thick, and, unless a careful watch had been kept upon the material that was being quarried and worked, I make bold to say that they would never have been found. At the present time, when the Cragg-Hill Quarry is not being worked, it is absolutely certain that no one could discover these layers on the quarry-face, and an average specimen of the grit would yield a totally erroneous result regarding the amount of heavy minerals, as I have computed that a garnetiferous layer is about 500 times as rich in heavy minerals as the normal grit.

It seems to be better for the present purpose to state the results, not in order of abundance only, but in a more general way with regard to the minerals present:-

(1) in the different lithological types of beds examined;

(2) in the succession of beds examined ;

(3) in separations from various localities.

(1) The different lithological types of beds may be arranged as follows :--

(a) Coarse grits and conglomerates containing pebbles half an inch or more in diameter: these yield chiefly-garnets, ilmenite and leucoxene, tourmaline, monazite, magnetite.

(b) Grits containing no pebbles more than half an inch in diameter: these yield - garnets, ilmenite and leucorene, tourmaline, monazite, rutile, magnetite.

(c) Grits containing no particles more than a quarter of an inch in diameter: these yield-garnets, ilmenite and leucoxene, tourmaline, monazite, rutile, zircon, magnetite.

(d) Sandstones, with grains about an eighth of an inch and less in diameter : these yield-garnets, zircons, rutile, tourmaline, monazite, ilmenite and leucoxene, magnetite. 
(e) Shales (arenaceous) : these yield-zircons, garnets, rutile, tourmaline, leucoxene.

( $f$ ) Shales (micaceous) : these yield-zircons, rutile, garnets, tourmaline, lencoxene.

The position in the list of minerals gives an indication of the relative abundance, the first-named being most plentiful.

It will be seen from this that the finer-grained the beds are, the more important berome zircon and rutile.

(2) Succession of beds examined.-For the purpose of this synopsis it will be unadvisable to enumerate every bed, as the localities are given in the table ( p. 270), but I simply divide the series into Lower, Middle, and Upper: the Jower to include all beds below the Leathley Sandstone of the 1-inch Geological Survey Map, Sheet 92 (Skipton), to the top of the Yoredale Shales and Limestones of Ingleborough, Penygent, Fountains Fell, etc.; the Middle division includes all beds from the Leathley Sandstone to, but not including, the Flags at the base of the Rough Rock, as shown on the map mentioned above; and the remaining Upper division all beds up to the Lower Coal Measures seen resting upon the Rough Rock at Whitehall Quarries, Butcher Hill, Horsforth.

(a) Lower Division.-Coarse beds (all conglomerates, grits, sandstones) contain garnets, ilmenite and leucoxene, zircon, tourmaline, rutile, monazite, magnetite. Fine beds (shales) contain zircons, rutile, garnets, tourmaline.

(b) Middle Division.-Coarse beds (grits and sandstones) contain zircons, rutile, garnets, tourmaline, ilmenite and leucoxene, magnetite, monazite. Fin e beds (shales) contain zircons, rutile, tourmaline, garnets. It must be stated here that in some of the separations made from the shales of Otley Chevin almost pure cultures of zircon were obtained, only a few grains and particles of rutile and tourmaline being present.

(c) Upper Division.-Coarse beds (grits and conglomerates) contain garnets, ilmenite and leucoxene, zircon, rutile, tourmaline, monazite, magnetite. Flags at the base of the Rough Rock contain zircons, rutile, garnets, tourmaline.

The striking fact which appears evident from this enumeration is that the heavy-mineral contents of the Lower and Upper divisions, so far as the coarse beds are concerned, are similar; while, in the Middle division, the garnets, which are the dominant mineral species in the other two, become subordinate to zircon and rutile.

The fine beds all through show very little differences, zircons being the most plentiful in them all.

Only two beds of shale of marine origin and yielding marine fossils have been examined. These were of the usual intense black, and exceedingly fine-grained. The only heavy minerals found were rhombohedral carbonates (presumed to be calcite), one or two grains of sulphide of iron, and one very small zircon.

It becomes quite clear from the results recorded above that the evidence yielded by the investigation of the included pebbles and the coarser material is borne out in an interesting manner by the presence of such heavy minerals as those described. 


\begin{tabular}{|c|c|}
\hline & 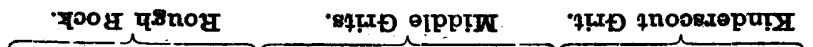 \\
\hline әұ!zвuо K & $\times \times \times \times \times \times \times \times \times \times \times \times \times \times:: \times \times \times \times \times \times \times \times \times \times \times$ \\
\hline$\because \mathbf{H d O} \mathbf{L}$ & 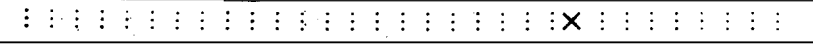 \\
\hline •ət!Yoo.ı & 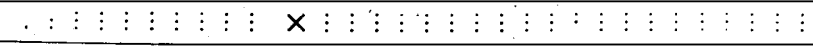 \\
\hline 'sejkIrgr & $\vdots \vdots \times \vdots \times \vdots \cdot \vdots: \vdots \vdots \vdots \vdots \vdots \vdots \vdots \vdots \vdots \vdots \vdots \times \times \quad \times \quad \vdots \times:$ \\
\hline 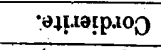 & 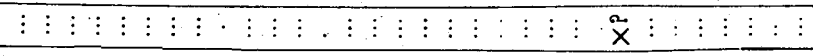 \\
\hline 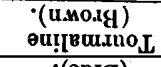 & $\times \times \times \times \times \times \times \times \times \times \times \times \times \times \times \times \times$ \\
\hline 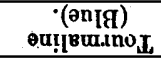 & $\times \times: \vdots \vdots: \vdots: \times \times \times \times: \vdots \times \times \times$ \\
\hline 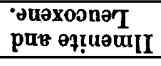 & $\times \times \times \times \times \times \times \times \times \times \times \times \times \times \times \times \times \times \times \times \times \times \times \times \times \times \times \times \times \times \times \times$ \\
\hline 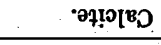 & $\vdots \vdots \vdots \vdots \quad \vdots \quad \vdots \times \quad \vdots \quad \vdots \quad \vdots \quad \vdots \quad \vdots \quad: \quad \vdots \quad \vdots \quad \vdots \quad \vdots$ \\
\hline •วu!̣ınөX & $\vdots \times: \vdots::: \quad \times \quad \times \quad: \times: \times: \times \times$ \\
\hline 'uoduz & $\times \times \times \times \times \times \times \times \times \times \times \times \times \times \times \times \times \times \times \times \times \times \times \times \times \times \times \times \times \times \times \times$ \\
\hline •өцุny & $\times \times \times \times \times \times \times \times \times \times \times \times \times \times \times \times \times \times \times \times \times \times \times \times \times \times \times \times$ \\
\hline$\cdot 28 B q B \| \mathrm{V}$ & 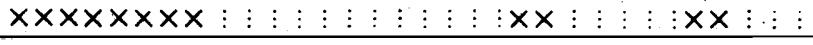 \\
\hline$\cdot 07 ! 9048 \mathrm{~K}$ & 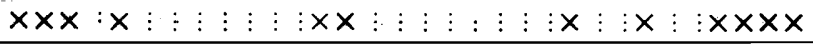 \\
\hline 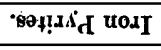 & 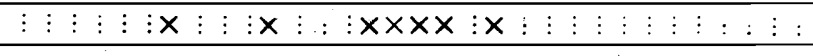 \\
\hline 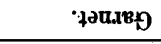 & $\times \times \times \times \times \times \times \times \times \times \times \times \times \times \times \times \times$ \\
\hline 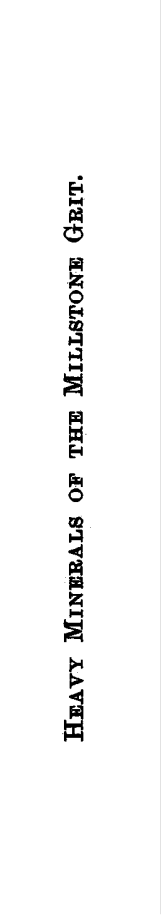 & 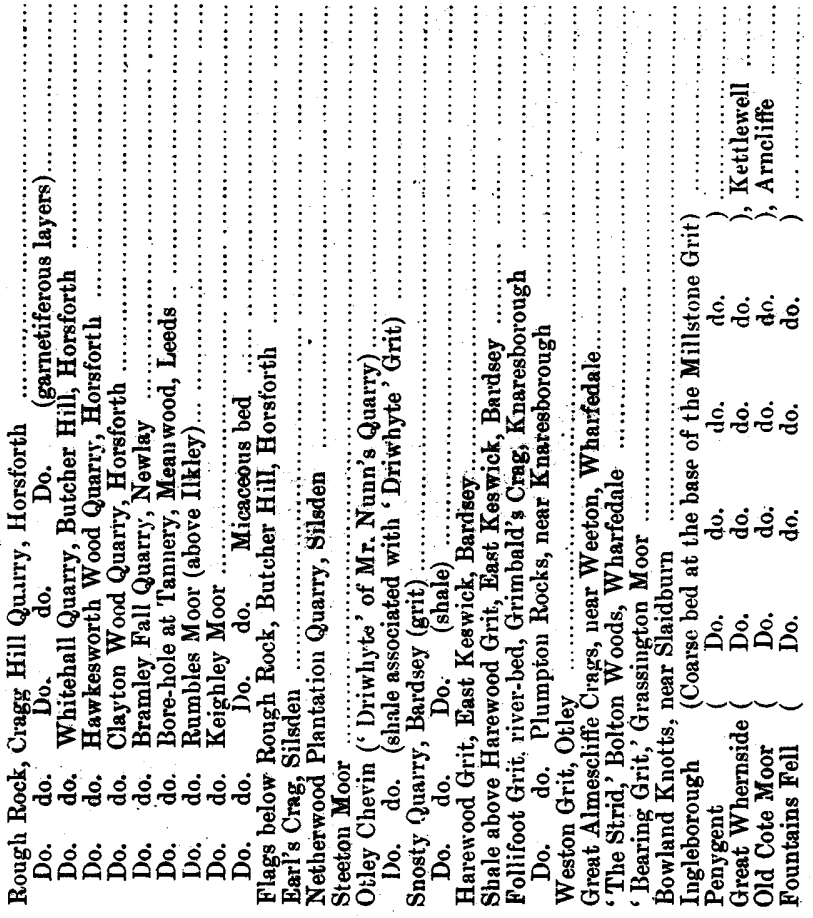 \\
\hline
\end{tabular}


The heavy minerals may be classified, according to the type of rock which is likely to have yielded them, as follows :-

Garnets-crystalline schists, gneisses, granulites, and granites.

Magnetite-crystalline schists, gneiss, and many igneous rocks.

Rutile-granite, crystalline schists.

Zircon-crystalline schists, gneisses, syenites, acid eruptive rocks.

Xenotime-granites and gneisses.

Tourmaline-granites and pegmatites, and, as shown later, schists.

'Topaz-granites.

Monazite-granites.

Cordierite-crystalline schists (since, however, this is so rare a mineral in the grits, the evidence is of little importance).

Ilmenite and its derivative leucoxene-scattered through igneous rocks, usually of basic type.

Anatase-This is, I believe, mostly of secondary origin, as stated above.

Brookite-granites and crystalline schists.

Iron pyrites--this is chiefly of secondary origin in the grits.

The most interesting of these minerals is undoubtedly the monazite, which, as shown in the lists, is present in almost all the beds examined, but chiefly in the coarser type, and most of all in the Rough Rock. When it was first determined to be monazite (February 1917) ${ }^{l}$ the only other records for the British Isles, so far as I am aware, were those made by Sir Henry A. Miers for Cornwall and by Sir Jethro Teall for Loch Dee Granite.2 It seemed to me, therefore, that here might be a crucial test for the theory of its derivation from a northerly source, and I find that Dr. W. Mackie has obtained this mineral in a large number of separations from granites of Northern Scotland. I have also, through his kindness, had the opportunity of examining a remarkable series of his slides showing the monazite and other minerals which he has so obtained. Dr. W. Mackie has given me his permission to quote his remarks, and they are here appended :--

' I have not so far published anything regarding monazite in the rocks of the North of Scotland, but I bave quite a number of observations regarding that mineral which have been accumulating for the last couple of years or more. I find it unexpectedly widely distributed in the granites of the North of Scotland; thus, out of 32 specimens of granite examined in this connexion, I find that monazite is present in 25 , xenotime in 23 , both minerals being found together in 18 . It is relatively abundant in the younger granites, e. g. in the red granites of Elginshire, while I have found it in some of the Shetland granites, e.g. that of Nesting. It' is also present in the Central Grampian granite, though not so abundantly in the specimens that I have hitherto examined; but perhaps the richest example that I have so far seen was in a sample from a xenolithic (probably older) granite included in the Central Grampian granite, which I took many years ago from the summit of Cairngorm. I find it in the grey granite of Aberdeen (Rubislaw), which is presumably one of the older granites. It occurs in many granites in welldefined crystals, in others in rounded or ovoid grains with rather corrodedlooking surfaces. ... In clastic rocks, e.g. in our local Upper Old Red Sandstones, I have found monazite, but so far not abundantly.'

1 I am indebted to Prof. H. L. Bowman for his kindness in making confirmatory spectroscopic tests of this mineral.

2 'Silurian Rocks of Britain, vol. i-Scotland'Mem. Geol. Surv. 1899, p. 619 . 
At a later date he writes:-

'Since I wrote to you about monazite I have looked into the matter a little farther, and have now made separations from 52 granites and have recorded the presence of monazite in 43-a very high proportion, as you see. It is less frequently present in the hornblende and sphene-bearing granites than in the simple biotite-granites or the muscovite-biotite granites; though it is not absolutely absent from the sphene-granites, it is certainly much rarer in these.'

I have practically nothing to add to these remarks of Dr. Mackie, except to point out that the granites which he found richest in monazite are precisely the types found in the Millstone Grit. Sphene I have not so far recorded : consequently, it would appear that sphene-bearing granites were not abundant in the area from which the material came.

\section{Heavy Minerals ix Pebbles fodnd in the Milustose Grit.}

Some of the pebbles of granite and schist were large enough to enable me to use a small portion for the separation of the heavy minerals without destroying the whole pebble, which would be most undesirable. The portion which was a vailable for such work was, however, too small to yield results that may be regarded as satisfactory, and the list is only given for what it is worth.

Perhaps the most remarkable result rielded by this part of the work is the abundance of rutile, zircon, and tourmaline in all the pebbles, whether granites or schists. Indeed, it will be seen that tourmaline is most abundant in the schists. Monazite is of somewhat rare occurrence, but that it should be found at all is a remarkable fact. Apatite is also recorded from three of the granites, while so far it has not been detected in any of the separations from the grit. 'This mineral is generally regarded as less liable to alteration than monazite, and is of common occurrence in sedimentary deposits generally, so that its absence from the grit is all the more remarkable. It must be noted, however, that apatite-needles have occasionally been observed in the quartz of the grit.

\section{Description of Minerals.}

Garnets.-These frequently show good crystal outline, but are more usually in a fragmentary condition. In a few cases they show the dodecahedral cleavage, and also contain inclusions; but all features due to alteration are, of course, absent.

Iron Pyrites.-This only occurs in one of the schists, and is in the cubical form, often as aggregates of small cubes.

Magnetite. - This mineral is also of rare occurrence, and does not show good crystal outline.

Anatase.-As in the case of the anatase in the grit, it is present most commonly as a derivative from leucoxene, and occurs as an outgrowth. A few good crystals have, however, been observed, and are of the tubular form with low pyramids. 
Rutile.-All the colours previously described as found in the grit are present in one or other of these separations. No geniculate or cordate twins have been found.

Zircon.-As would be expected, these in nearly all cases show good crystal outline, of the forms described for the zircons in the grit. Zonary structure is common, as are also inclusions of various forms.

Xenotime.-This is similar to the zircons in form, but is of reddish or reddish-brown colour, and somewhat larger than the majority of the zircons.

Ilmenite and leucoxene.-As was noted in the grit, ilmenite is by far the commonest of the iron-bearing minerals, and is associated with leucoxene--with anatase- and rutile-crystals as secondary outgrowths.

Tourmaline.-The long pyramid is the common form, terminated by rhombohedra in a few cases. The colour is brown to purplish, and is strongly pleochroic. Blue tourmaline has been noted in the separation from the schist.

A patite.-As stated, this mineral has not been recorded from the grit, and is only of rare occurrence here, the form being acicular.

Topaz.-This occurs in only one of the granites, and is of irregular form, with good basal cleavage developed.

Monazite.-Its presence in these granites is most interesting. The mineral is often rounded, but one good crystal has been noted.

An interesting and important light upon the question whether the rocks of the Lake District contributed material to the Millstone Grit has been given by the work of Mr. R. H. Rastall \& Mr. W. H. Wilcockson upon the accessory minerals of the Lake-District granites. ${ }^{1}$ They find that some of the most abundant of the heavy minerals of the grit, such as rutile and tourmaline, are by no means common constituents of these granites, while sphene proves to be common in the Lake-District granites and absent from the Millstone Grit. Apatite also is common in these granites and absent from the grits, but it must be noted that it occurs in three of the pebbles from the grit. The crucial test, however, seems to be the monazite. When the paper above quoted was read before the Geological Society, Dr. H. $H$. Thomas, replying to the discussion on behalf of the Authors, stated that, although searched for spectroscopically, monazite had not been detected. Apart, then, from the question whether the granites of the Lake District could or could not, by reason of their exposure, have contributed material to the Millstone Grit as previously discussed, there are here definite reasons for excluding them as possible sources for the material making up the Millstone Grit Series of the Yorkshire area.

1 Q. J. G. S. vol. lxxi (1915-17) pp. 592-622. 
Heaty Mrnerals in Pebeles found in the Millstone Grit.

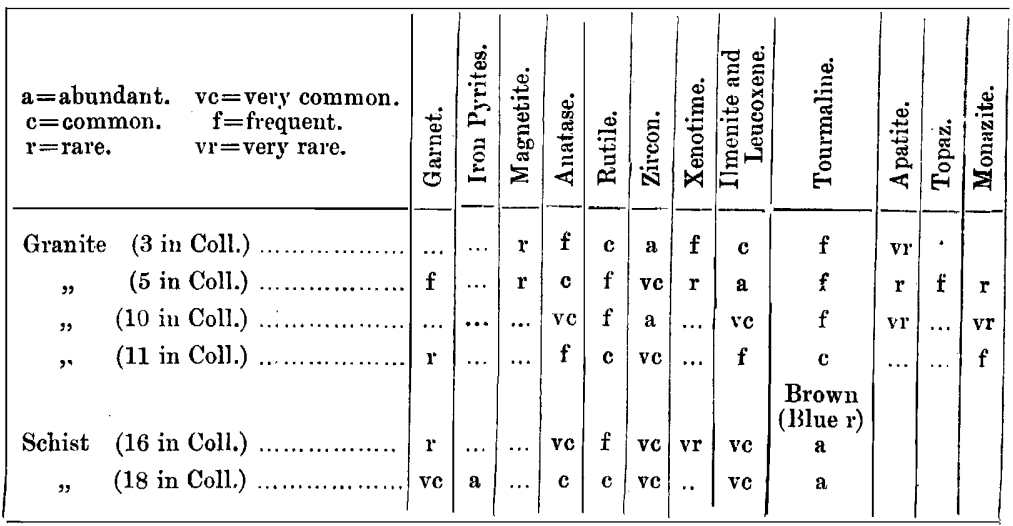

We may now sum up the evidence of the lithological characters.

Pebbles of the following types have been found and examined:Gneisses, schists (of various types), granites, pegmatites, quartzand felspar-porphyries, quartz, felspar, quartzites, cherts, sandstones, and mudstones.

The large quartz-pebbles, which are the most plentiful of all the pebbles in the grit, are of such shape and microscopic structure as to make it certain that they have been derived from rocks which have been subjected to intense shearing, while strain-shadows are invariably present. The smaller pebbles and grains of quartz are commonly of a bluish or opalescent tint, the colour being due to inclusions of various types-regular, irregular, and acicular; while liquid inclusions with movable bubbles are exceedingly common.

The dominant felspar of all the beds is microcline. This occurs in large tlesh-coloured pebbles, commonly about $\frac{1}{2}$ inch in diameter, and is always quite fresh and unaltered even when it has been exposed on the face of a quarry or building for a considerable period. It occurs plentifully, too, as smaller grains in the mass of the grit or shale, where it is also quite unaltered. Other types of felspar found are microcline-microperthite, oligoclase, and a little orthoclase. The oligoclase and orthoclase are frequently altered, and I am of the opinion that the greater part of the altered felspar found in the grit has been derived from this source.

Pebbles and grains derived from sedimentary rocks are plentiful, by far the most abundant being chert (of various colours). In some of these, as already noted, traces of organisms and welldefined oolitic structure are found (see Pl. XVIII, figs. 4-6). These must represent the solution and decay of limestone-beds.

Sandstone pebbles also occur, sometimes of large size; while altered mudstone and mudstones with organisms are included in the series. 
It is, moreover, worthy of note that in the coarse beds the larger grains (quartz, felspar, etc.) are frequently well rounded, while the smaller grains are always angular.

\section{Lithodogical Characters of the Land-Mass from the Denudation of which the Material of the Millstone Grit was derived.}

The first and by far the most important rock making up this ancient land-mass must have been a granitoid gneiss of very acid composition, which was ramified by veins of pegmatite. Unaltered granites must also have been present, but the evidence of crushing found in the great mass of the quartz of the Millstone Grit makes it quite certain that they only formed a subordinate portion of the whole mass. The dominant felspar in these rocks must have been microcline, the large pebbles of this felspar being derived from the pegmatites. The presence of mica-schist and quartz-schist, and also the abundance of mica in the shales, sometimes making up beds 2 to 3 feet thick of almost pure white mica, make it safe to infer that schists of various types constituted a large portion of the land. 'The garnets which are so common would in large part have been yielded by the schists. The volcanic rocks, quartz, and felspar-porphyries are significant as showing the presence of dykes of acid character, which were to be found traversing all or any of the other rocks present.

The abundance of chert-pebbles (sometimes showing oolitic structure) with cryptocrystalline and microcrystalline silica, often with rhombs representing carbonates, enable us to draw the inference that limestones containing chert-bands, and also in part silicified, were associated with the igneous and metamorphic rocks. Other sedimentary rocks, such as grits, sandstones, and mudstones, must also have been present, as pebbles of such rocks occur in the grit. Some of the rounded quartz-grains found in the grit may possibly be of contemporaneous origin; but I am strongly disposed to think that the greater number have been derived from pre-existing grits and sandstones, and therefore such types must have formed part of this ancient land-mass.

\section{Divisions of the Milistone Grit Series.}

The area occupied by the Millstone Grit Series from Derbyshire to Yorkshire was surveyed under the direction of the late Prof. A. H. Green (who formerly occupied the Chair of Geology at Leeds University). In the Memoir of the Geological Survey on the Yorkshire Coalfield, 1878, the following observations are recorded as a result of the work of the Survey (p. 27) :-

'Subdivisions of the Millstone Grit in the North Central Counties.

Rough Rock-Almost invariably a coarse and massive felspathic grit about. 100 feet thick. A band of flagstone frequently at the base. Called Shales. also First Grit. 
Second Grit-A somewhat variable group of finely-grained sandstones and shales.

Shales.

Third Grit-A coarse massive gritstone between 200 and 300 feet thick, remarkable for its regular jointing and bold wall-like escarpments. Shales, Fine flaggy beds at the base, and a coal on the top frequently.

Kinderscout Grit-Coarse, often conglomeratic, very massive, with occasional bands of flagstone. Where most largely developed, in two beds with shale between. Up to 500 feet thick. Also called Fourth Grit.'

Marine bands are found at different horizons in the shales of the whole series, perhaps the most notable in Yorkshire being that exposed in Cayton Gill, north of Harrogate. When the excavations were being made for the dam of the Eccup Reservoir, Leeds, a marine band was found yielding perhaps the richest fauna ret discovered in the Millstone Grit, and I have described elsewhere a series of five such marine bands passed through in a borehole at the Tannery, Meanwood, Leeds. ${ }^{1}$

Coal-seams are also of frequent occurrence throughout the series, but increase in number and thickness towards the top, and have in many places been worked, though the coal is usually of inferior quality.

The subdivisions given above were found to apply well enough as the work of surveying and mapping proceeded in Derbyshire and South Yorkshire; but, as it was carried farther north, some modification had to be introduced, as it was no longer possible to identify with certainty the so-called Second and 'Third Grits, and it was found better to apply the term 'Middle Grits' to the large number of separate grit-beds which occur between the Kinderscout Grit and the Rough Rock. These upper and lower beds could still be identified by their lithological characters and stratigraphical position.

\section{ViII. Mode of Accumelation of the Material.}

The assemblage of beds which make up the series is such as to leave no reasonable doubt that the material represents the deltaic deposits of some large river comparable in size with such a one as the Mississippi, and doubtless, in the same way as that great river, receiving tributaries from regions where climatic conditions were of very different types. One has only to study the literature of such deltas as those of the Mississippi, Ganges and Brahmaputra, Irrawadi, or Nile, to realize the close resemblance between such present-day deposits and the Millstone Grit of Yorkshire. Indeed, one may go so far as to say that a study of our modern deltas is absolutely essential to the understanding and correct interpretation of the problems connected with the Millstone Grit and the succeeding Coal Measures. It may be well to give an estimate of the amount of material accumulated over the area of Yorkshire

1 Trans. Leeds Geol. Assoc. Part xviii. (To be published.) 
in Millstone Grit times. The area covered in Yorkshire by this series at present is no less than 840 square miles; while if we take into account that which lies beneath the newer rocks, and that where it can be safely assumed to have occurred (but is now only represented by outliers on such hills of the Pennine Chain as Ingleborough, Whernside, Penygent, etc.), an area of 2000 square miles once occupied by Millstone Grit would be a safe assumption. If we take 1000 feet as the average thickness, this would represent 400 cubic miles; or it may be built into the form of a range of hills, which would be 800 miles long, 1 mile in diameter at the base, and 1 mile high.

Now, since it is an axiom in geology that deposition is a measure of detrition, we may form some idea of the vast amount of material which was removed from some pre-existing land-surface. This is all the more evident when it is remembered that in such an estimate as that given above, only Yorkshire has been considered, and the amount would have to be multiplied by a large factor were the Millstone Grit of other areas in the Midlands and North of England, etc., to be taken into account.

\section{Position of the Ancient Land-Mass.}

If we take first the position, the discussion will gain in clearness if a survey is taken of the Millstone Grit as it occurs in Lancashire and Yorkshire, and to the south in Staffordshire, Derbyshire, Cheshire, and Leicestershire. In papers by $\mathrm{E}$. Hull and $\mathrm{A}$. $\mathrm{H}$. Green ${ }^{l}$ describing the Millstone Grit of these areas, it is shown very clearly that there is a very pronounced attenuation of the series where traced towards the south and south-east. In the summary given at the end of the first paper mentioned, it is stated:-

'We have now traced the Millstone Grit from the borders of Lancashire and Yorkshire, where it contains five thick beds of massive gritstone and reaches a thickness of 2800 feet, to the borders of the North Staffordshire Coalfield, where only two of these beds are left, and where the whole thickness is not more than 200-300 feet. We find the Rough Rock ...... present everywhere and keeping pretty much the same thickness throughout, but losing altogether its coarseness and massive character in the south. The Haslingden Flags, the second bed, maintain their thickness and character unchanged until they thin away somewhat suddenly about 5 miles south-west of Buxton. The Third Grit runs through the whole of the district; but, from a thickness of more than 400 feet, which it reaches in Lancashire, it lessens down to about 100 feet in the neighbourhood of Congleton, and still further south seems to be on the point of dying out altogether. Though this bed becomes without doubt finer to the south, it keeps more than any other a certain massiveness of structure to the last ..... The passage of the fourth or Kinderscout rock from an enormous mass of gritstone and conglomerate 1000 feet thick into two beds of finer gritstone with a shale between, north of Buxton, has been pointed out, as also the further change which the latter undergo into still finer sandstones, and their total disappearance in the Biddulph and Rudyerd basins.'

The sections which are given to illustrate this attenuation are here reproduced (see fig. 1, p. 278).

1 Q.J. G.S. vol. xx (1864) pp. 242-67; also ibid. vol. xxiv (1868) pp. 319-23. Q. J. G. S. No. 300 . 


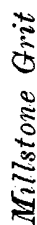

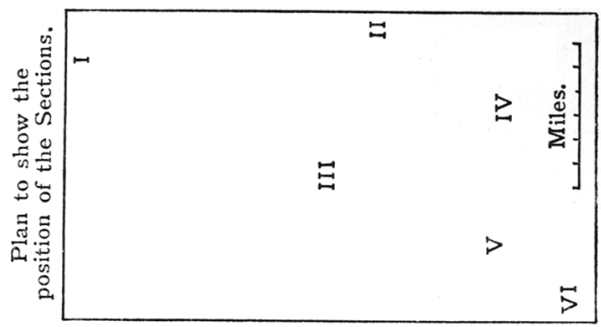

$\frac{1}{6}$

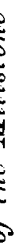
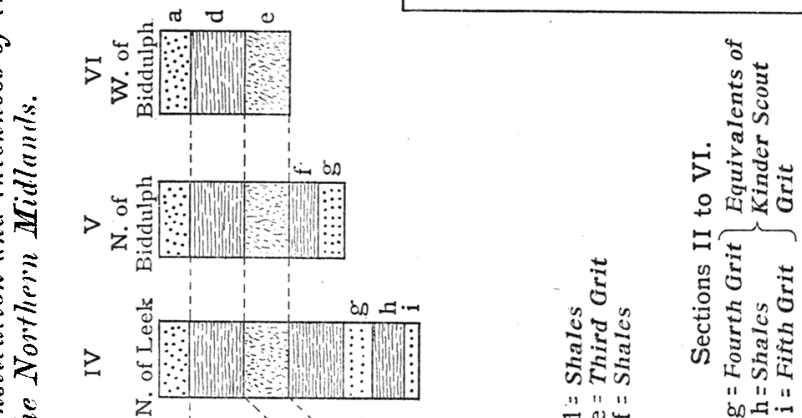

约

曰

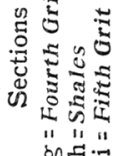

$\stackrel{0}{\circ} \underset{0}{*}$

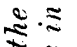

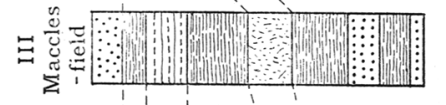

ons...

焉兽焉

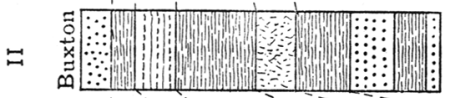

㟧

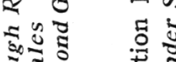

ธิง

"艹

范

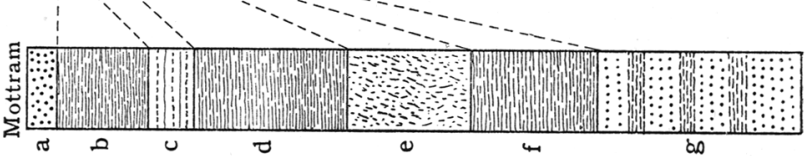

$\frac{10}{10}$

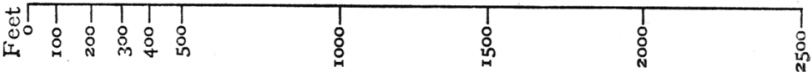

In the second paper by Hull, ${ }^{1}$ written after a more detailed examination of the district round the Pendle Range, the following comparative vertical sections are given of the Carboniferous strata from North Lancashire to Leicestershire :-

$\begin{array}{ccccc} & \begin{array}{c}\text { Burnley } \\ \text { District. } \\ \text { Feet. }\end{array} & \begin{array}{c}\text { Mottram } \\ \text { District. } \\ \text { Feet. }\end{array} & \begin{array}{c}\text { North } \\ \text { Staffordshire. }\end{array} \\ & \text { Feet. } & \text { Feet. } \\ \text { Coal Measures........... } & 8640 & \mathbf{7 6 3 5} & 6000 & 3000 \\ \text { Millstone Grit Series ... } & 5500 & 2500 & 500 & 50 \\ \text { Yoredale Series ......... } & \mathbf{4 6 7 5} & \mathbf{2 0 0 0} & \mathbf{2 3 0 0} & 50\end{array}$

1 Q.J. G.S. vol. xxiv (1868) pp. 319-23. 
In the Geological Survey Memoir on the Yorkshire Coalfield, 1878 , the diagram (pl. $i$, facing p. 32) showing the variations in the grits when traced from Ashover (south-west of Chesterfield) to the neighbourhood of Skipton, makes the fact of the increase of thickness to the north very clear.

The only possible conclusion to which we can come from the facts set forth above is that the material of the grit series was derived from some northerly source.

The central barrier of St. George's Land, as it has been termed, must be excluded as a possible source for more than a small fraction of the material in the grit, for the following reasons :-

(a) It has not the necessary lithological character.

(b) The area is altogether inadequate.

In considering $(b)$ it must be remembered that a large portion of the barrier which existed in Lower Carboniferous times had been covered by the encroachment of the Carboniferous Limestone. This central barrier precludes the possibility of derivation from the south of it.

The Lake District has also been cited as a possible source of supply of material, and it has been suggested that the large felspars of the grit have been derived from the Shap Granite, ${ }^{1}$ which is quite erroneous. The recent work of Prof. E. J. Garwood ${ }^{2}$ in mapping and zoning the Carboniferous Limestone of the North of England shows that the Lake District represented an area of subsidence in Lower Carboniferous Limestone (Avonian) times and was submerged beneath the waters of the so-called Avonian ocean.

In Scotland, land was to be found in the Southern Uplands in Lower Carboniferous times, and, according to J. G. Goodchild, material derived from this area is to be found in the beds of the Basement Carboniferous of the North of England. When, however, we enquire how much of the area was exposed in Millstone Grit times after the covering of Lower Carboniferous rocks had been laid down, it is found to be quite inadequate to supply any large proportion of the Grit Series of Yorkshire, though it possibly contributed to the homotaxial deposits farther north. Here, again also, in applying the lithological test, one is bound to conclude that it rules out this area: for, while the large quartz-pebbles of the coarse grits and some of the micaceous material of the shales could have been derived in part from (or, perhaps it would be better to say, resemble some of) the rock-constituents of the Southern Uplands, the pebbles of fresh felspar and pegmatite found so abundantly in the coarse beds of the Millstone Grit most certainly did not come from that district. Also the granites forming the highest points in Galloway are notably rich in sphene, a mineral not found so far in the Grit.

By this process of elimination, I am forced to the conclusion

1 R. D. Roberts, 'Introduction to Modern Geology' 1893, p. 244.

${ }^{2}$ Q.J.G.S. vol. lxviii (1912) p. 553. 
Downloaded from http://jgslegacy.lyellcollection.org/ at University of Liverpool on June 30, 2016

Fig. 2.

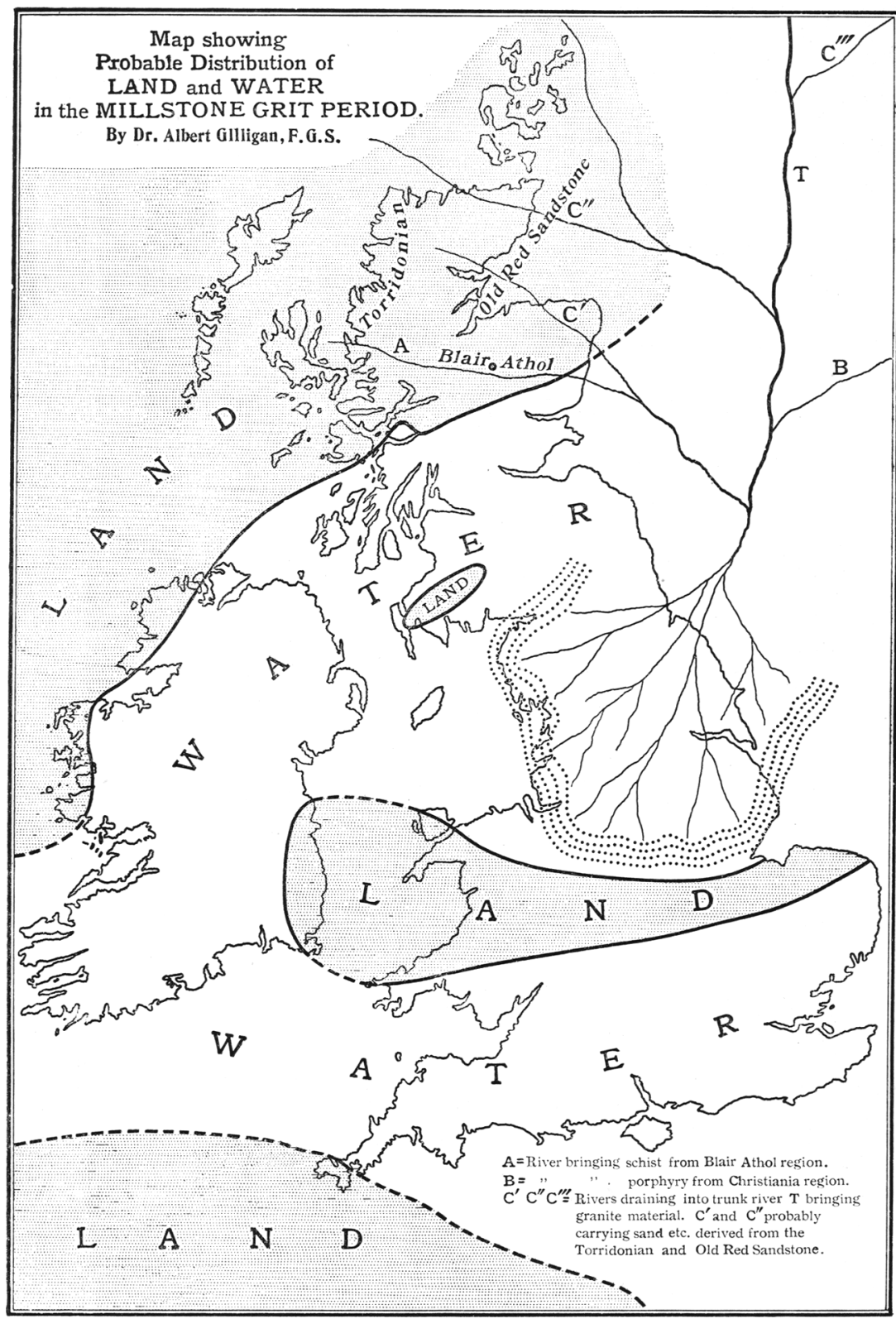


that the only possible area lay still farther north, in what is now the North of Scotland, and its extension lay east with a larger Scandinavia, thus forming part of a great continental land, the limits (northern and western) of which it is not at present possible to define. This is a conclusion to which previous workers in the same field have arrived, namely, Sorby, ${ }^{1}$ and Hull, ${ }^{2}$ while their views have been endorsed by Green. ${ }^{3}$ The last-named quotes Sorby on this subject, and, in the map which he gives of Lower Carboniferous geography, we find that he has represented the boundary of the extension of this Scoto-Scandinavian land as lying quite close to the present eastern coastline of the Northern counties of England, crossing it at Spurn Point into Lincolnshire, and joining up with the Central Ridge before mentioned. An isthmus of the Southern Uplands connects it with a large land-mass which sends off a tongue to embrace the north of the Isle of Man and the Lake District, while another large lobe to the west takes in the North-West of Ireland. The Central Valley of Scotland forms an inlet open to the ocean in the west.

A. J. Jukes-Browne ${ }^{4}$ criticizes this map, and proposes to join up the North of Ireland with Scotland north of the Central Valley, and to open a way between the South of Ireland and the South of England. In his own map ${ }^{5}$ he has made these alterations, and introduces changes in the boundaries of the Central Ridge, which he connects up with Ireland and the SouthWest of Scotland. It is not my intention to discuss the boundaries of the Lower Carboniferous Sea: I have merely given these references and descriptions, in order to make it clear that all workers in this subject agree that the great northern land-mass did exist, and that Scotland and Scandinavia were undoubtedly connected in Carboniferous times.

Only Sorby, however, had adduced any evidence from the lithological side, and all subsequent writers to the present time have been content to quote his work, the reliability of which has never been questioned, and the result of the work herein described is to confirm the view put forward by Sorby some sixty years ago. This northern land satisfies the conditions required as to type of rock: though many of the pebbles which are here figured and described cannot be definitely traced, yet one cannot fail to be impressed with the resemblance when the whole facies is taken into account. (See map, fig. 2, p. 280.)

\section{Physical Relief of the Ancient Land-Mass.}

The Carboniferous Limestone was certainly not deposited in a sea of great depth; on the contrary, it exhibits throughout its

1 Proc. Yorks. Geol. \& Polytechn. Soc. vol. iii (1859) p. 675.

2 'Physical History of the British Isles' 1882, p. 37; and Trans. Roy. Dublin Soc. ser̄. 2, vol. iii (1885) p. 305.

3 'Coal : its History \& Uses' 1878 , p. 38.

4 'Building of the British Isles' 2nd ed. (1892) p. 131.

s Ibid. p. 123. 
whole thickness undoubted evidence of shallow-water conditions. One need only adduce as evidence of this the types of fossils which make up so large a part of the rock and the general broken condition in which they are found. The great thickness which the limestone attains in some parts is accounted for by its accumulation upon a subsiding sea-floor. Whence was the calcareous material derived? The old continental land which had been subjected to denudation during Old Red Sandstone times must have been considerably lowered by the supply of material for the formation of those beds, further it seems most probable that the rivers draining the old land would have base-levelled themselves so far, and would be draining land of such low relief, that they would no longer be able to bear along much material in suspension, and that they would have assumed the characters of old rivers in which the proportion of material in solution would be greatly increased. No duubt much of the calcium carbonate was derived from pre-existing calcareous deposits, the carbon dioxide merely acting as a carrier of the calcium carbonate from land to ocean. "To this cause, that is, the solution and carrying away of the calcareous material, may be attributed the abundance of chert-pebbles found especially in the lower beds of the Millstone Grit, these representing the insoluble parts of the limestone.

But no area of pre-Carboniferous limestone would be of sufficient extent to supply the calcium carbonate in this way : much of it must, therefore, lave been derived by a process of leaching, and so it seems that a great amount of carbon dioxide drawn from the atmospheric-ocean supply must be locked up in the Carboniferous Limestone. The bearing of this will be dealt with later, when the question of the climate of Millstone Grit times is discussed. Here it is sufficient to note that this process of leaching would result in a thick cover of rotted rock being left over the low ground and along the river-courses of the old continent. There is little evidence for determining the directions of the rivers of the Carboniferous Limestone period, but they must have been chiefly from the northern continent, the quantity of material accumulated rendering a large drainage-area necessary. The Yoredale Beds which sueceed the Carboniferous Limestone in the North of England represent the removal of the rotted material from the old land-surface by reason of the rejuvenation of the rivers caused by uplift at the source, and its being carried forward to be spread out and deposited upon the old continental shelf upon which the lime-secreting animals of the Carboniferous Limestone period had flourished. This removal of the covering layers of the soil would prepare the land for yielding a fresh supply of unleached rock, and it is only by the upheaval of such a prepared land-surface that it seems possible to satisfy the conditions demanded by the Millstone Grit. That uplift of the great Northern Continent was taking place, producing instability and establishing a line of weakness along its southern edge, the direction and position of which is almost exactly defined by the northern edge of the Central Valley of Scotland, 
seems evident from the fact that this region, from Devonian right through Carboniferous to Permian times, was the locus of intense volcanic action. Oscillations of level and unequal subsidence are the concomitant features which we naturally find in such an area. This line was, it would seem, the limb of a great earth-fold, and the line of weakness so determined gave rise to the volcanic action cited above, as in similar circumstances we have lines of volcanoes to-day. Generally, then, the physiography of the opening stages of the Millstone Grit period may be represented by saying that folding was again taking place along the old Caledoniani axes, bringing into existence a great earth-wave, the crest of which is represented by the Northern Continent and the trough by the South of scotland, Ireland, and the North of England. 'That successive uplifts went on during Millstone Grit times is traceable in the fact that we have coarse beds at the base (Kinderscout), finer material in the Middle Grits, and coarse again in the Rough Rock, and in the Coal Measures we note again the fine-grained detritus succeeding the Rough Rock and comparable with the Middle Grits. It is most remarkable that the dominant constituents, both of the larger fragments and the smaller grains, should be the same in the Kinderscout Grit and in the Rough Rock, showing that the main source of supply must have been the same in both cases. With regard to the height to which the land was ridged up in the Northern Continent there is no definite evidence, but it must have been considerable, in order to cause so great a condensation of moisture as it is absolutely necessary to predicate, in order to supply the volume of water for the large rivers which transported the detritus of the Grit and Coal Measures, and it would indeed seem to me that the relief of the land must have been of Himalayan grandeur.

\section{Xi. Drift- or Current-Bedding in the Grit.}

As was pointed out by Dr. Sorby, in the paper already cited, trustworthy information as to the direction from which the material composing deltaic deposits has been brought by the rivers is afforded by an examination of the drift- or current-bedding to be found in all such deposits. It must be remembered that, in applying such a test, absolute agreement in the compass-bearing of such bedding, either in the same vertical section or over any wide area, is not to be expected, but some prevalent direction must emerge when a sufficiently large number of readings are taken. Suppose, for instance, a great river with a correspondingly extensive delta, such as the modern Mississippi. In flowing over its delta the distributaries will cary forward material in directions which make a considerable angle with the main river and with each other, as in the diagram (fig. 3, p. 284), and the angle between the two outermost distributaries may exceed $180^{\circ}$. Moreover, these distributaries have meandering courses, which further complicates matters. Nevertheless, in the compass-bearing of the current-bedding 
the main direction of the main river will be found in a large proportion of the readings: as in the diagram, north-east to south-west, and north-west to south-east, the main direction being from north to south. Again, the distributaries will have their

Fig. 3.-Diagram illustrating courses of distributary streams in a great river. delta.

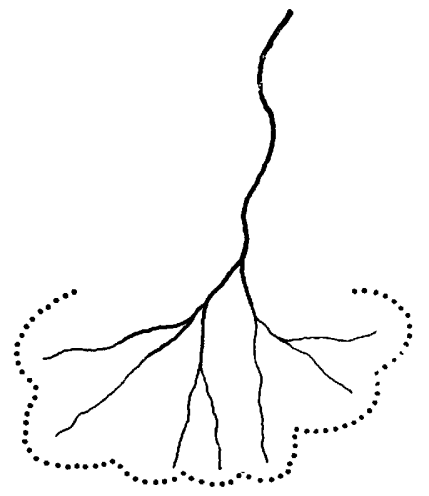
courses altered from time to time, and the current-bedding would not therefore be in the same direction in a rertical section. Pursuing this line of investigation, I have found, in agreement with Sorby, that the prevalent direction is north-east to south-west. Sorby made his observations in South Yorkshire, while mine have been made in Airedale, Wharfedale, and Nidderdale, as well as on outliers of grit on Ingleborough, Fountains Fell, Whernside, Bowland Knotts, Penygent, etc. The best place to make such tests is, of course, on isolated masses of grit such as can be found in plenty on the tops of the hills mentioned, as well as in the low ground in such well-known areas as Plumpton Rocks and the similar masses near Spofforth and Scriven.

The frequent occurrence of beds of pebbles in such currentbedded grits as those mentioned above is of great interest, and of course they represent the heavy pebbles which have rolled down the slope of an advancing sandbank.

\section{Comparison with the Torridon Saydstone.}

As the investigation proceeded, it became increasingly evident that there was a striking similarity in composition between the Torridon Sandstone of pre-Cambrian age found in the North-West of Seotland and the Millstone Grit of the North of England. I have, therefore, had sections of the Torridon Sandstone prepared for comparison, and found a very pronounced agreement in all essential points, the most marked difference being the rounding of the grains in the Torridon Sandstone as compared with the general angularity of the grains in the Millstone Grit. One has only to read the chapter on the petrography of the "Torridonian Formation' in the Geological Survey Memoir on the North-West Highlands of Scotland, and to compare it with the petrography of the Millstone Grit, as revealed by this investigation and here recorded, to be convinced of the strong resemblances of the two deposits.

It is, of course, natural that in the basement-beds of the Torridonian should be found pebbles derived from the underlying 
formations ; in fact, they represent the screes formed on the slopes of the old land-surface upon which the Torridonian rocks were laid down. The conditions which obtained during the time, and the area of deposition of the basement-beds, of the Millstone Grit, were of course quite different.

Further, complete agreement even in the general constituents of the two formations cannot be expected, since, as I have already mentioned, some part of the allothigenous material of the Millstone Grit must necessarily have been derived from rocks of later age than the Torridonian, and situated in areas which were unlikely or impossible sources of the material that makes up the Torridonian.

The following comparison will illustrate the resemblances and differences :-

\section{TORRIDONIAN.}

(a) Presence of blue or opalescent quartz with acicular, irregular, and regular inclusions.

(b) The dominant felspars are microcline, microcline-microperthite, oligoclase, and orthoclase. The characteristic felspar of the arkoses is microcline and microcline-perthite, quite fresh and unaltered.

(c) Cherts of various colours showing cryptocrystalline or microcrystalline structure. No definite organisms have yet been found.

(d) Silicified oolite, in which the oolitic grains are defined by small spherical bodies and pseudomorphs in the form of rhombs showing their derivation from calcareous rocks.

(e) Quartzite-pebbles.

(f) Pebbles of vein-quartz, which show evidence of shearing, are the most abundant.

(g) In the larger pebbles are found felsites, gneiss, mica-schist.

(h) Clastic micas (both brown and white) are present in the finer-grained beds.

(i) The heavy minerals include magnetite, ilmenite, sphene, garnet, tourmaline, zircon, and rutile; Dr. T. O.Bosworth (Rep. Brit.Assoc. Dundee, 1912 , p. 474) points out the great abundance of garnet and zircon.

\section{MrLLSTONe GRIT.}

(a) Similar pebbles abundant in the grit.

(b) Microcline, microcline-microperthite, oligoclase, and orthoclase occur, but microcline and microclineperthite are by far the most abundant in the coarse grits and quite fresh to the outside.

(c) Cherts of various colours showing similar structure are common in the coarse beds. Some ghosts of organisms are found in a few of the chert-pebbles.

(d) Exactly similar pebbles have been found, in which the small round bodies are about the same size as in the pebble figured and described in the N.W. Highland Memoir, p. 280 \& pl. 1, fig. 1. See Pl. XVIII, fig. 5.

(e) Quartzite-pebbles.

(f) This is also the case with the Millstone Grit. See figures.

(g) Pebbles of similar types are here figured from the Grit.

(h) Clastic micas (both brown and white) are present in the finer-grained beds; sometimes the white mica makes up beds from 2 to 3 feet thick with only a small admixture of quartz, felspar, and oxide of iron (e.g., below the Rough Rock, Keighley Moor).

(i) The heavy minerals include ilmenite and leucoxene, garnet, zircon, tourmaline, rutile, and monazite. Of these by far the most abundant is garnet; while zircon is very common in all the beds, but especially in the Middle Grits and Rough Rock. 
The Torridon Sandstone is believed to have come mainly from the north-west, the abundance of microcline making it impossible that it should have been derived for the greater part from the underlying Archaean rocks, whtle it also contains pebbles of rocks which do not occur in Scotland. If that deduction be correct (as I believe it is ) for the derivation of the Torridonian, then it would also appear that here is confirmation of the conclusions already arrived at from other evidence with regard to the source of material of the Millstone Grit.

Further, it must be mentioned that the Sparagmite of Scandinavia is a group of red arkoses and sandstones some thousands of feet thick, and is found over a great extent of country north of Christiania. It bears a striking resemblance to the Torridonian of Scotland, and was in all probability derived from the same source. It appears that the chief point of difference between the Torridonian and the Millstone Grit is due to the mode by which these two series of beds were accumulated. It is now agreed that the Torridonian Series represents a continental deposit, thereby accounting for the evidence of wind-action which it yields in the rounding of the grains and the presence of 'dreikanter.' The Millstone Grit, on the other hand, is undoubtedly an ordinary deltaic deposit, having been borne along with great rapidity by large rivers, of which it represents the coterminous deltas. Some of the beds of Millstone Grit which are stained red, such as the Plumpton and Follifoot Grit near Knaresborough, are sufficiently like the Torridonian to deceive anyone when examined in a hand. specimen, but a lens reveals the better rounding of the grains in the Torridonian.

If we assume, then, a river fed by streams rising among the mountains to the north, possibly fed in many cases by the meltwaters of glaciers descending from the snow-fields, such a river would receive tributaries on both banks, bringing in material from the Grampian Highlands and Scandinavia, as well as from the Southern Uplands, and possibly of land which occupied what is now the North Sea. These tributaries from Scotland and Scandinavia can be traced on the evidence of the black schist from Blair Athol, and on that supplied by the felspar-porphrry which is probably one of the facies of rhomb-porphyry of the Christiania region described previously. The old river first debouched into the Carboniferous Sea somewhere off the coast of North-Eastern England, laying down the beginnings of its delta, possibly in Lower Carboniferous times. With the first uplift of the Northern Continent the carrying power of this river increased, while its tributaries again became active agents in removing the material as previously suggested. 'The engrafting of the tributaries upon the larger river would take place as the deltas grew. 


\section{Chimatic Condirions.}

In all considerations of ancient climates the distribution of land and water must play an important part, as was long ago pointed out by Humboldt and Lyell, for it is the deep circulation brought about by Polar currents and the corresponding spreading of the equatorial waters towards the Poles which are the fundamental elements in bringing about equable distribution of surface temperatures. How may this be applied to the Millstone Grit period? If the conclusions at which I have arrived with regard to the uplift of this great Northern Continent be correct, then the epicontinental area upon which the lime-secreting animals of the Lower Carboniferous had existed would have been considerably reduced, and a southward recession of the northern boundary of the ocean must have followed. Dr. A. Vaughan has shown ${ }^{1}$ that such a recession is observable in South Wales. The Lower Tournaisian shore is represented on the map drawn up to illustrate his paper as an enbayment connected with the south-western channel, which at its northern limit extended to the Clee Hills. In Upper Viséan times the shore-line of the south-western channel ran just north of Bristol and continued in a straight line to Pembroke. The whole neck of land which contained the 'Barrier' shifted with a wave-like motion southwards as Viséan times proceeded. Whether this uplift of land excluded the oceanic waters altogether from the circumpolar regions at any time is not clear. The collections made by Col. H. W. Feilden, of the Nares Polar Expedition, and described by R. Etheridge, ${ }^{2}$ obtained chiefly from lat. $82^{\circ} 40^{\prime} \mathrm{N}$., clearly established the occurrence in these high latitudes of Carboniferous limestone rocks. The facies is North American and Canadian, although many of the species are British.

In the paper by Col. Feilden and C. E. De Rance (op. cit.), it is stated

'that a continuation of the direction of the known strike of the limestones of Feilden Peninsula, carried over the Polar area, passes through the neighbour. hood of Spitsbergen, where this formation occurs, and contains certain species identical with those of the Grinnell-Land rocks of this horizon.' (P. 560.)

'The explanation of the presence here of Carboniferous Limestone is somewhat difficult, except that it may be accounted for by an opening from the Carboniferous ocean of North America, so giving communication for the passage of those species which are identical with those of the Carboniferous Limestone of North America.

Etheridge, in the paper above cited, pp. 573-74, says :-

'No Triassic strata have been detected either in this or any previous expedition; whether, therefore, either the Permian and Trias seas, or both, aided in the denudation of the Carboniferous group, or their sediments were deposited and then denuded before the deposition of the Lias, which rests upon the Eglinton-Island Carboniferous Limestone, must still remain an undetermined question. It would therefore almost appear that it must have

1 'Avonian Shore-Lines' Rep. Brit. Assoc. Manchester, 1915, pp. 429-31.

2 Q. J. G.S. vol. xxxiv (1878) pp. 568-639. 
been a continental land through elevation of the Carboniferous group, until the northern extension of the Liassic seas to these high latitudes. The complete absence (so far as we know) of Permian and Triassic strata in the Parry or Northern archipelago goes far to confirm this. Not a trace of any organic remains younger than the Carboniferous Limestone and older than the Miocene has occurred to Feilden and Hart, or to any of the other explorers during their researches in these high latitudes.'

This uplift of the northern area at the close of Carboniferous Limestone times premised by ktheridge is fully corroborative of the general uplift of continental dimensions which is certainly demanded by the Millstone Grit Series, and therefore the closing of the gulfs or fiords would naturally follow. 'That the same southward recession of the shore-line took place on the western side of the Atlantic, in America, is quite clear, for there the Mississippian or Lowel Carboniferous is overlain by the Pottsville Conglomerate (the deposit which is homotaxial with our Millstone Grit) in the east, which grades westwards and south-westwards into sandstones, and with local conglomeratic phases the sandstone is found over the interior of the continent. This conglomerate and sandstone is composed of material derived from the Archæan which lar to the north. It is thought that the conglomeratic beds of the east represent the earlier stages of the epoch, and that, as the period of deposition was prolonged, the detrital material spread westwards and southwards. The analogv, therefore, with Britain would seem to be complete. Chaniberlin \& Salisbury have estimated that the sea was excluded from an area of about $20,000,000$ square miles at the close of the Carboniferous Limestone period.l

The physical conditions of the Millstone Grit period with the high land to the north, probably forming a continuous belt for some thousands of miles from Europe across the Atlantic, and embracing part of Northern America, with deltas encroaching upon the ocean to the south, would determine a climate of a monsoon type. The warm southerly winds would bear an abundance of water-vapour to be condensed on ascending the slopes of the high land and capable of feeding the great rivers of this period, which in their rejuvenation would soon clear off all the rotted rock left by the leaching processes of the preceding period. The relief of the land previously discussed may have been such as to nourish an icefield and its attendant glacial phenomena; but the snow-line would necessarily be at a fairly-high altitude, on account of the proximity of the warm southern ocean and the warm winds which would blow therefrom.

Weathering of the rocks would be chiefly by mechanical means, in which chemical action played a minor part. As was first pointed out by the geologists of the Indian Survey, ${ }^{2}$ it is possible to determine whether mechanical or chemical agents have been the

${ }^{1}$ T. C. Chamberlin \& R. D. Salisbury, 'Geology : Earth History' vol. ii (1906) pp. 658-59.

2 H. B. Medlicott \& W. T. Blanford, 'Manual of the Geology of India' 2nd ed. by R. D. Oldham (1893) p. 201. 
most active in causing the break-up of a granitic rock by an examination of the felspars found in deposits resulting from such action. If the felspars are fresh and unaltered, the inference is that the break-up of the original rock has been brought about by mechanical means. The freshness of the felspars in the deposits at the foot of the Himalayas and in the Gangetic basin they believed was due to the disintegration of the parent rock by frost and ice. J. W. Judd, in his descriptions of the Nile deposits, speaks of the freshness of the felspars, ${ }^{1}$ and points to the area from which they have been derived as undergoing disintegration by the unequal expansion of the minerals of the rocks consequent upon the heat of the sun by day and the subsequent cooling by radiation at night. From the commencement of my investigations the exceeding freshness of the felspars of the Millstone Grit has been one of the main points which has been quite clear. Many of the photographs accompanying the present paper show this, and there can be no question of subsequent formation within the grit itself. Even in the minute fragments found in some of the finer-grained beds, which would, of course, be more easily affected than the large ones on account of the proportionately larger surface, many of these plagioclase felspars show no trace of decomposition. The microcline is indeed well known to be the most resistant of the felspars: in all the grits this felspar occurs, both in the large pebbles and in the small grains. in the most perfectly fresh condition, and when a large pebble is fractured the cleavage-faces are often as bright and lustrous as possible. The kaolinization noticeable in some of the grit-beds, as in the Rough Rock of Horsforth, has evidently been brought about since the rock has been exposed in post-Carboniferous times, the original outline of the felspars being usually traceable.

When discussing the source of the calcium carbonate in the Carboniferous Limestone, I pointed out that much of it must be due to leaching of calcareous material from silicates of the alkaline earths: this would necessarily mean an abstraction of the carbon dioxide from the atmospheric-oceanic supply, causing a considerable diminution in that substance. This would leave the Millstone Grit period with a much depleted supply, so that the freshness of the felspars in the Grit and the formation of the Carboniferous Limestone are in consonance one with the other, chemical agents being active in the formation of the latter and of little importance in the former. In fact, this period may be looked upon as one when the atmospheric-oceanic supply was being replenished.

As Judd, in the paper above quoted, pointed out, an examination of the clays (if modern deposits) or shales (if ancient deposits) should yield evidence of the amount of chemical decomposition which the parent rocks have undergone. If kaolin is the chief constituent, then chemical action has been responsible to a great extent; but, if

1 Proc. Roy. Soc. vol. xxxix (1886) pp. 215-17. 
they consist of the same minerals as the coarser beds, only in a finer state of subdivision, then mechanical agencies have been dominant in causing the disintegration of the original mass. I have applied this test to the shales of the Millstone Grit, and find that they are composed in a large part of mica with which are associated finely-divided quartz and felspar and an abundance of heavy minerals, such as zircons and rutile, in beds that do not carry marine fossils. These latter are quite different from the normal shales, so that in an exposed section it is possible for anyone acquainted with these marine shales to identify them at once, on account of their exceedingly fine texture, quite different from the normal shales, and on analysis they yield a greater amount of water, pointing to their composition being much more like that of kaolin than the normal shales. Was it glaciation or insolation which was more active in Millstone Grit times? There is no evidence of the former, while everything points to the latter as being extremely probable, and to this opinion I strongly incline. It may be, as previously pointed out, that the height of the old continental land was such as to nourish an icelield in the same way as at present; we have such conditions in the Himalayas. If, however, the high mountains were bordering the sea during the earlier part of the period, as would appear to have been the case, in the area under review at least, then their flanks facing south would have been kept free of ice by the proximity of the warm water laving the shore. As the deltas grew seaward the distance between the ocean and the foothills (which were continually decreasing in height by the intense denudation that they were undergoing) would be increasing, and so the climate of the same tract of country would be passing from one approximating to an insular climate to the continental type. At the same time, with the decrease in height of the hills, the area above the snow-line would decrease, especially near the shore-line, where the effects of denudation would be felt most severely. It seems to follow, therefore, that the part played by ice was a quite subordinate one, and that it was confined to the work of an icefield or several isolated icefields, the descending glaciers from which never reached very far down the mountain-valleys.

In conclusion, I wish to express my sincere thanks to those who have so kindly assisted me in many ways. To Prof. T. G. Bonney, Prof. H. L. Bowman, Prof. W. C. Brögger, Dr. Herbert H. Thomas, and Mr. George Barrow, for help in the identification of rocks and minerals; also to Dr. J. Horne, Mr. J. Holmes, and Mr. G. F. Pickering, who have generously supplied me with specimens of rock and of pebbles. To Prof. P. F. Kendall I express my thanks for his interest and helpful advice on many occasions in the long period during which the work has been in progress. 
part 4] THE MILLSTONE GRIT OF YORKSHIRE.

\section{EXPLANATION OF PLATES XV-XVIII.}

\section{Plate XV.}

Fig. 1. Quartz-pebble from Kinderscout Grit, The Strid, Bolton Abbey. The specimen is a good example of mylonitization, with evidence of shearing in the elongated patches of quartz, well seen in the photograph. $\times$ about 20 diameters. (See p. 262.)

2. Pebble of blue quartz from the Middle Grits near Ripon. The acicular inclusions are well shown, as are also the liquid inclusions which contain movable bubbles. $\times$ about 110 diameters. (See p. 254.)

3. Pebble of black quartz from the Rough Rock, Cragg-Hill Quarry, Horsforth. A very common type, the strain-shadows and 'mortarstructure' resulting from pressure prior to inclusion in the grit. $\times$ about 20 diameters.

4. Pebble of microcline from the Rough Rock, Cragg-Hill Quarry, Horsforth. $\times$ about 20 diameters. (See p. 254.)

5. Pebble of felspar from the Rough Rock, Clayton-Wood Quarry, Horsforth. This also is a common type, consisting of a microperthitic intergrowth of microcline and oligoclase. $\times$ about 20 diameters. (See p. 254.)

6. Kinderscout Grit, Embsay Moor, near Bolton Abbey. The freshness and rounding of the microcline is noticeable, and the term 'arkose' is correctly applied to such a rock.

\section{Plate XVI.}

Fig. 1. Rough Rock from borebole, at a depth of 125 feet, Meanwood, Leeds. Fresh plagioclase felspar is uncommon. $\times$ about 20 diameters. (See p. 262.)

2. Pebble of quartz-porphyry, from the Middle Grits, Silsden. The ground-mass shows traces of devitrification, and the quartz is often much corroded. $\times$ about 20 diameters. (See p. 256.)

3. Pebble of quartz-porphyry from the Middle Grits, Silsden. This differs in type from that illustrated in fig. 2 , in that it contains much decomposed and corroded ortboclase. $\times$ about 20 diameters. (See p. 256.)

4. Pebble of porphyry from the Middle Grits, Silsden. In the groundmass quartz and felspar occur in micrographic intergrowth of an extremely minute character. The felspars are chiefly albite and oligoclase, with some orthoclase. $\times$ about 25 diameters. (See p. 256.)

5. Pebble of pegmatite, from the Kinderscout Grit, Skipton. Pegmatite consisting of quartz intimately intergrown with microcline (which is very fresh) and microperthite. $\times$ about 20 diameters. (See p. 255.)

6. Pebble of pegmatite from the Rough Rock, Cragg-Hill Quarry, Horsforth. In the hand-specimen the quartz appears opalescent, and shows under the microscope inclusions similar to those seen in Pl. XV, fig. 2. The dark areas with good crystal outline are caused by the removal of felspars during the slicing process. $X$ about 20 diameters. (See p. 255.)

\section{Plate XVII.}

Fig. 1. Pebble of granite from the Middle Grits, Silsden. This is the largest pebble yet obtained from the Millstone Grit, measuring 10 by 8 by 4 inches. It is of a general pink colour, with large white and grey patches of altered felspars. Hornblende and biotite both much altered, with separation of iron-oxides. The biotite has numerous small zircons enclosed. $X$ about 25 diameters. (See p. 255.) 
Fig. 2. Pebble of granite from the Middle Grits, Silsden. The felspar is oligoclase, very fresh, often enclosing quartz. A little homblende is present. $\times$ about 25 diameters. (See p. 255.)

3. Pebble of granite from the Middle Grits, Silsden. Quartz (opalescent), fresh felspar, and muscovite are distinguishablc in the hand-specimen. The felspar shows curved lamellæ, and encloses blebs of quartz. $\times$ about 25 diumeters. (See p. 255.)

4. Pebble of granite from the Middle Grits, Silsden. This appears to be a fine-grained felspathic gneiss, but under the microscope shows no trace of having been crushed. The rock is a protoclastic granite, singularly fresh. $\times$ about 25 diameters. (See p. 256.)

5. Pebble of quartz which encloses a fragment of mica-schist, from the Middle Grits, Silsden. The quartz bears evidence of shearing. The mica-schist is of the nsual type. Vermicular chlorite occurs in the quartz. $\times$ about 20 diameters. (See p. 256.)

6. Pebble of mica-schist, very much contorted, from the Middle Grits, Silsden. Garnets with good erystal outline are present, but frequently part of the garnet has been replaced by some other isotropic mineral which has not been determined. $\times$ about 20 diameters. (See p. 256.)

\section{Plate XVIII.}

Fig. 1. Pebble of black lustrous mica-schist from the Middle Grits, Silsden. Magnetite has separated out prior to the final folding, as it has conformed so well with the lines of folding. Quartz is fairly abundant, while no fresh felspar can be detected. $\times$ about 25 diameters. (See p. 257.)

2. Pebble of black lustrous mica-schist from the Middle Grits, Silsden. Quartz is fairly abundant. Muscovite and biotite are the principal constituents, together with a white chlorite. Much black dust occurs in the felspars. This is the pebble identified as the Black Schist of the Blair Athol-a-Nain district. $\times$ about 25 diameters. (See p. 257.)

3. Pebble of greenish slaty rock, with pronounced folding, from the Middle Grits, Silsden. The most noticeable feature is the beautiful microfoliation with a tendency to strain-slip cleavage. $\times$ about 25 diameters. (See p. 257.)

4. Pebble of black chert from the Kinderscout Grit, The Strid, Bolton Abbey. A fine-grained chert, deeply stained with iron-oxide and in part isotropic. One edge shows typical oolitic structure. $\times$ about 25 diameters. (See p. 257.)

5. Pebble of grey chert from the Plumpton Grit, Knaresborough. The "oolitic grains have their borders defined by a number of small rounded bodies, which do not show any organic structure. Numbers of these bodies occur scattered through the rock apart from the oolitic grains. The section bears a striking resemblance to a pebble from the Torridon Sandstone, described in the North-West Highland Memoir, p. $280 \&$ pl. 1, fig. 1. $\times$ about 25 diameters. (See p. 257.)

6. Pebble of black chert from the Rough Rock, Cragg-Hill Quarry, Horsforth. By ordinary light outlines of organisms can be seen, probably sponge-spicules. In polarized light no trace of these organisms can be seen, and the rock appears to $b_{3}$ made up of small grains of quartz embedded in a fine-grained siliceous matrix. $\times$ about 25 diameters. (See p. 258.) 


\section{Discession.}

The SECRETaRY read the following remarks, received from Dr, B. N. PEACH :-

'I had the opportunity of reading the Author's MS. on 'The Petrography of the Millstone Grit Series of Yorkshire' when it was presented as a thesis. for the D.Sc. degree at Leeds University. I was impressed with the exhaustive character of the research and the thoroughness of the Author's. detailed methods. His investigations throw much light on the petrographical characters of these coarse sediments and the probable region from which the main constituents were derived. I agree generally with his conclusions. $\mathrm{He}$ has established, in my opinion, that a great part of the constituents of the Yorkshire Millstone Grit closely resemble those found in the Torridonian arkoses of the North-West Highlands. It seems a reasonable conclusion that the materials in this deltaic deposit in Yorkshire were borne by a great. river, from a continental land-area in the North where granitic rocks were exposed to denudation similar to those that supplied the abundant microclinein the Torridon Sandstone. The abundance of optically-strained quartzgrains, the micas, the pebbles of chloritoid rock and rhomb-porphyry suggest that the river flowed over, or received tributaries from, a region which is now Scotland on the one side and Scandinavia on the other. This conjecture is greatly strengthened by the study of the heavy-residue minerals, especially of the rare monazite, which the researches of Dr. Mackie of Elgin have proved to be comparatively common in the schists and pre-Carboniferous granites of Scotland.'

Dr. H. Lapworth asked whether the Author's researches had enabled him to distinguish the various grit horizons that made up the series. In North Derbyshire the speaker found little difficulty in recognizing and separating the lower grits one from the other in the field; but in Yorkshire and other areas the individual beds. appeared to have no marked characteristics.

Dr. H. H. Thomas said that he was deeply interested in the work that the Author had carried out. He was especially impressed with the extreme abundance, relatively speaking, of certain of theheavy detrital minerals described, unore especially of monazite; for, although the speaker had proved that it was of fairly general occurrence, having found it in the alluvium of the Trent, in the blown-sands of the Hampshire Coast, and the Irish-Sea Drift of Wales, the amount obtained was always inconsiderable. The speaker congratulated the Author, and expressed the opinion that the communication which had just been made to the Society constituted the most complete account of the petrography of a sedimentary series that had ever yet been published.

Mr. W. H. WILcocksos asked whether the Author had detected any trace of pyrrhotite in the Millstone Grit. In work on the sandstones in the Denbighshire Grit Series of North Wales, the speaker had found this mineral in fair quantity in several of the coarser grits, such as the Corwen and Pen-y-Celog-Grits, and that not only in the unweathered parts, but in the bleached surface-layers. In the Welsh grits these layers contained specks of iron-oxide, which seemed to have resulted from the decomposition of some of the sulphide mineral, and similar specks of iron-oxide

Q. J.G.S. No. 300 . 
PETROGRAPHY OF YORKSHIRE MILLSTONE GRIT. [rol. lXIv.

were noticeable in the weathered portion of some of the Millstone Grits.

The President (Mr. G. W. Lampluah), in closing the Discussion, asked whether the Author's investigations had yet been extended to the sandstones of the Jurassic area in the North Riding of Yorkshire.

The AUthor, after thanking the Fellows for their kind reception of his paper, said that work upon the rocks of the Jurassic System of Yorkshire was just being taken up at Leeds University, and it was proposed to examine, in due course, the Estuarine Sandstones, which offer problems similar to those dealt with in the paper, Answering Dr. Lapworth's question, he said that correlation of the lenticular sandstone and grit-beds of Central and Northern Yorkshire had not been definitely attempted; but he was convinced of the use of such methods for that purpose, in the same way as had been attempted by Dr. T. O. Bosworth for the sandstones of Carboniferous age in Scotland. Dr. Thomas's statement regarding the widespread distribution of monazite in recent deposits was of great interest, and he hoped that its source would be definitely traced. Pyrrhotite had not so far been discovered in the beds of the Millstone Grit Series, but abundant sulphide of iron occurred in the Coal-Measure Sandstones, and it was quite possible that some of this was pyrrhotite. 
1 .

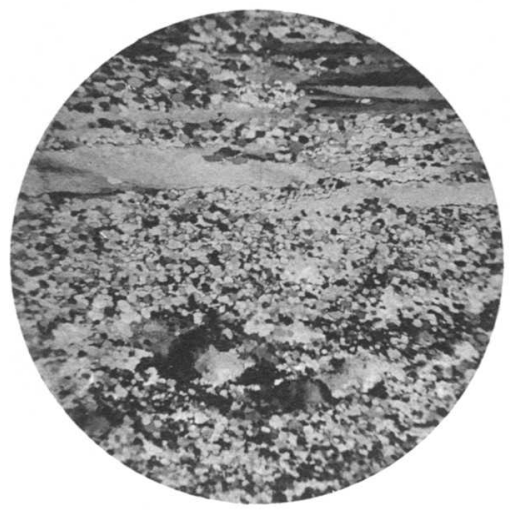

3.

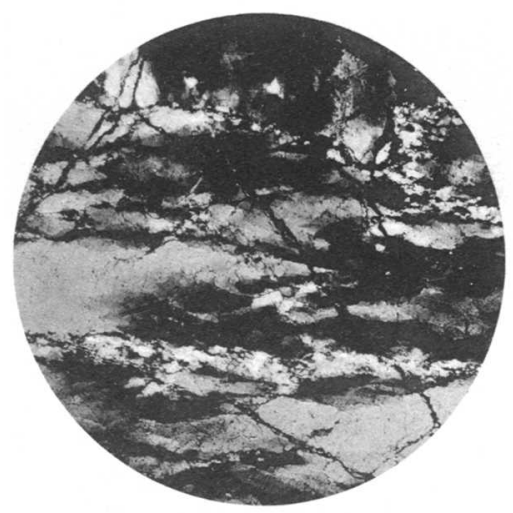

5.

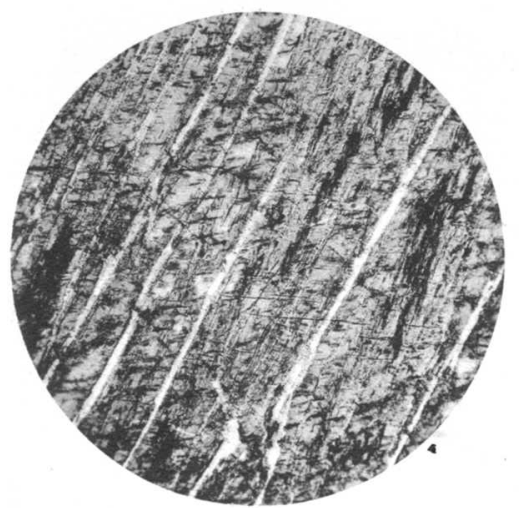

2.

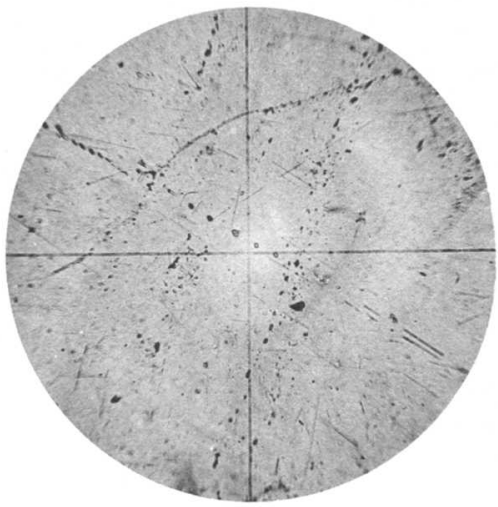

4.

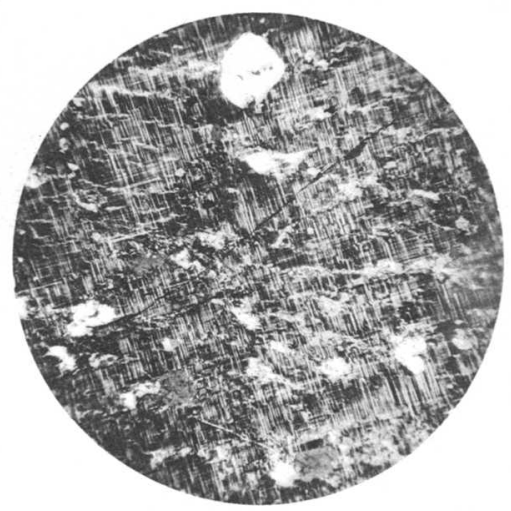

6.

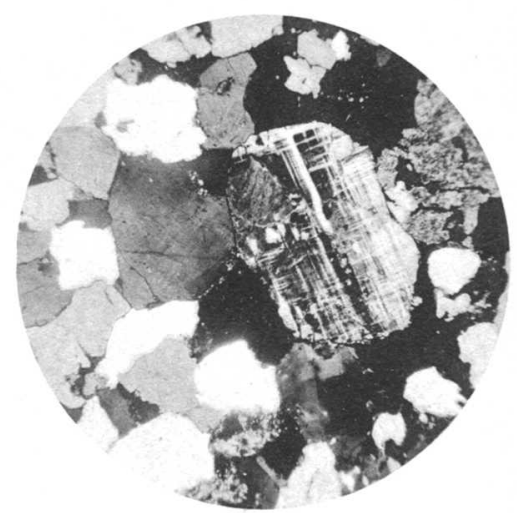

A.G., Microphoto.

Bemiose. Collo. Derby.

PEBBLES FROM THE MILLSTONE GRIT OF YORKSHIRE. 
Junjart. Jojourn. Geol. Soc. Vol. LXXV, Plixvi.
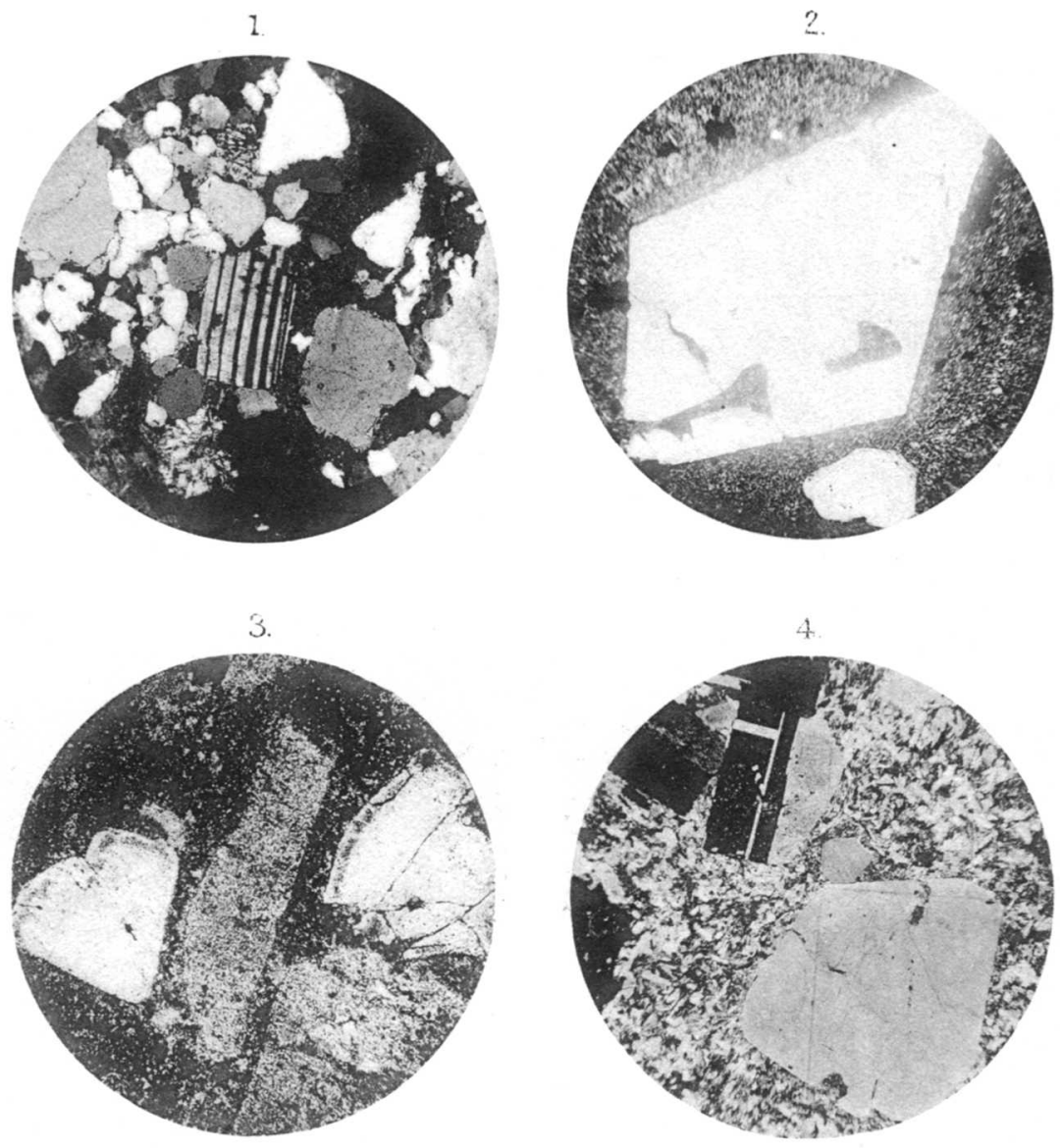

5.

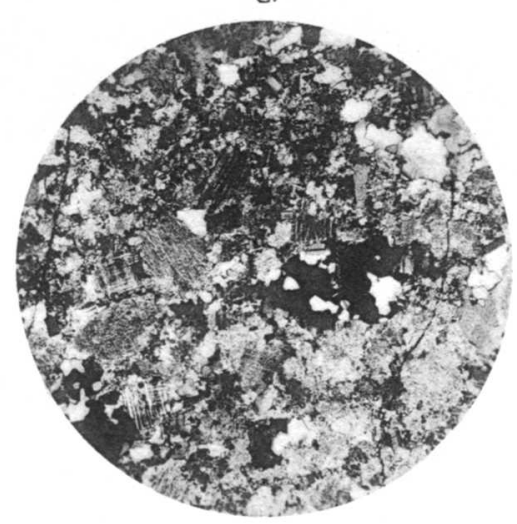

6.

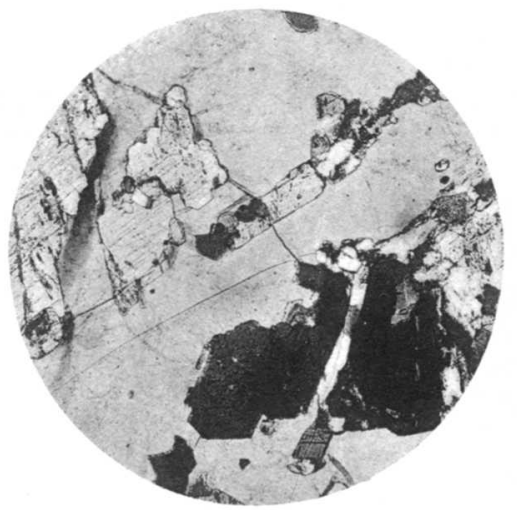

A. G., Nicrophoto.

Bemrose, Colio, Derby

PEBBLES fROM THE MILLSTONE GRIT OF YORKSHIRE. 
1

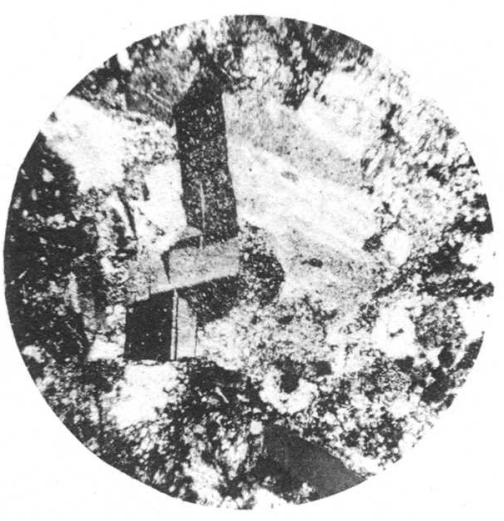

3.

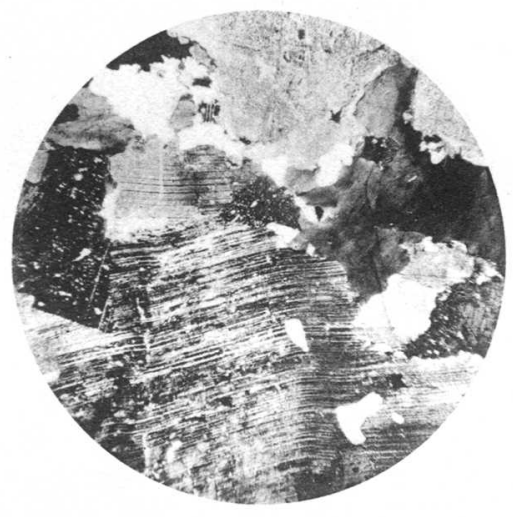

5.

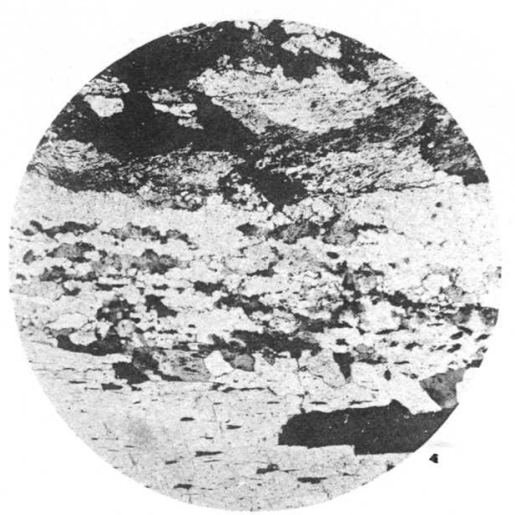

2

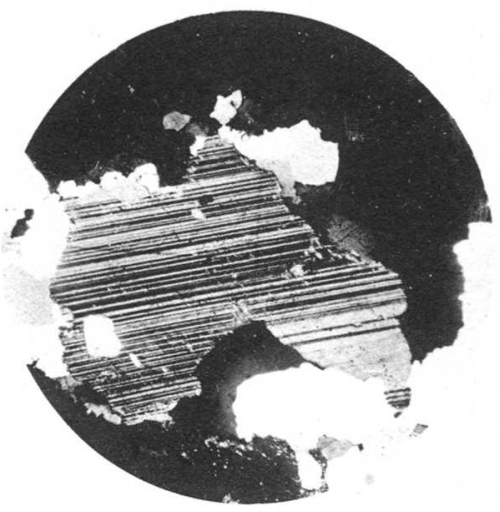

4.

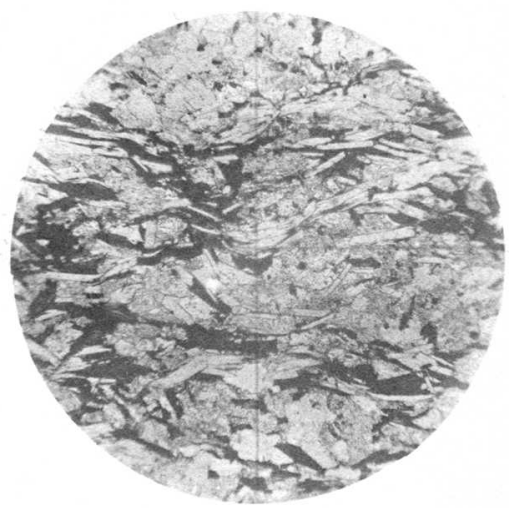

6.

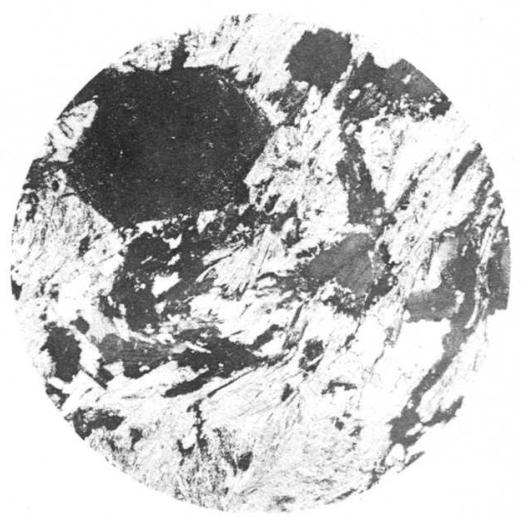

A.G., Microphoto. 
1.

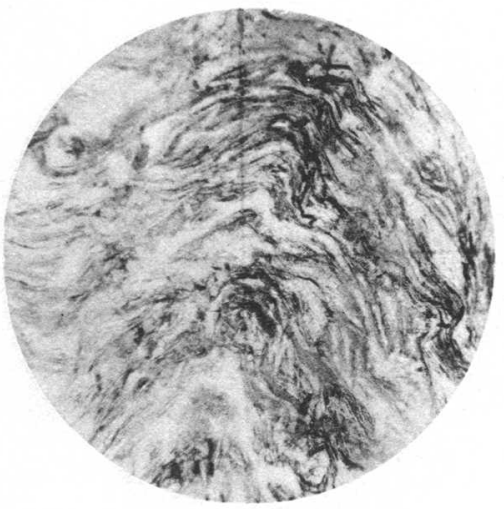

3.

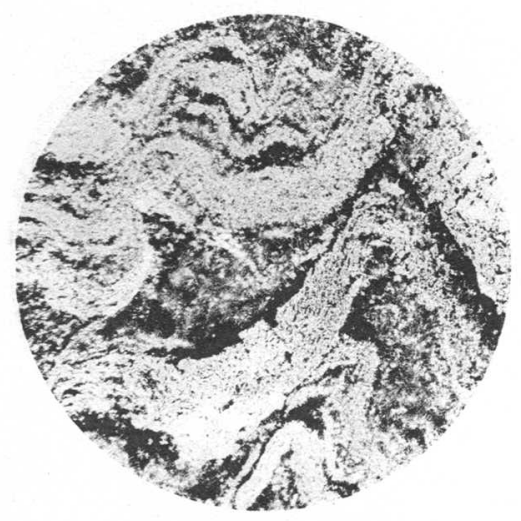

5.

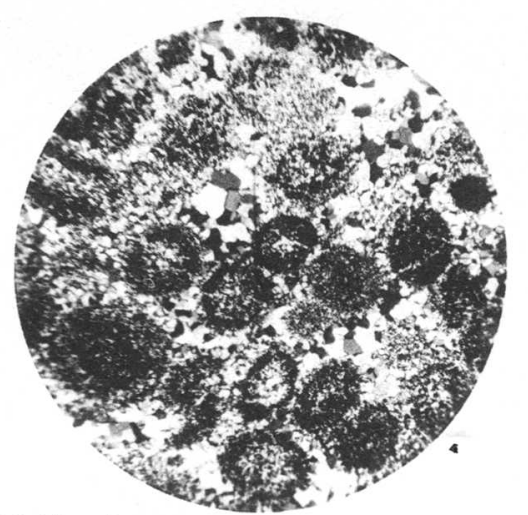

2.

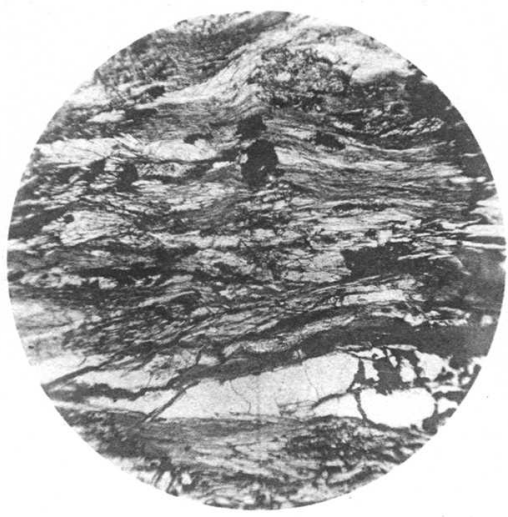

4.

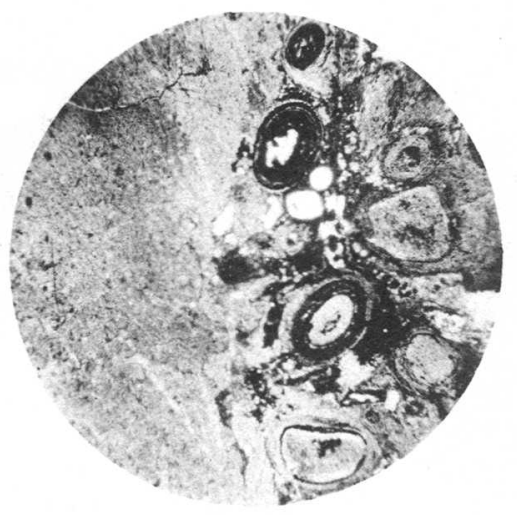

6.

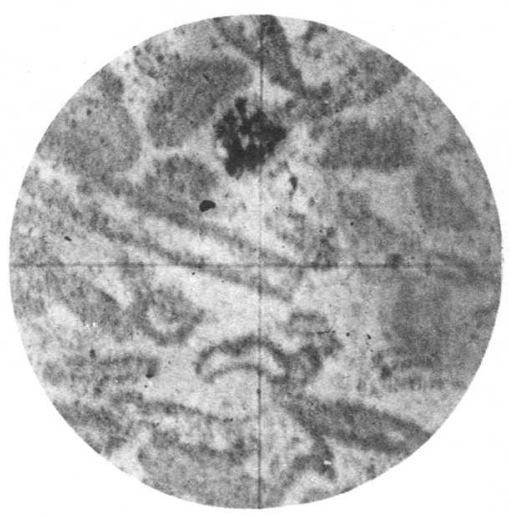

A.G., Microphoto.

Bemrose. Collo. Derby.

PEBBLES fROM THE MILLSTONE GRIT OF YORKSHIRE. 